Chapter 4

\title{
Physiological Dysfunction in Fish After Insecticides Exposure
}

\author{
Mahdi Banaee \\ Additional information is available at the end of the chapter \\ http://dx.doi.org/10.5772/54742
}

\section{Introduction}

A fundamental contributor to the Green Revolution has been the development and application of insecticides for the control of a wide variety of insectivorous and herbaceous pests which would otherwise diminish the quantity and quality of food production (Ecobichon, 2001). Unfortunately, in spite of its advantages, chemistry has great disadvantages as well. Insecticides are threatening the long-term survival of major ecosystems by disruption of ecological relationships between organisms and loss of biodiversity. On the other hand, agriculture, as the largest consumer of freshwater and as a major cause of reduction of surface and groundwater resources through erosion and chemical runoff, are close related to the loss of water quality (Wauchope, 1978). The processing industry associated to agriculture is also a significant source of organic pollution in most countries. Conventionally, in most countries, all types of agricultural practices and land use, including animal farming, are treated as nonpoint sources. The main characteristics of non-point sources are not simply determined or controlled directly and therefore, are difficult to regulate their impacts on ecosystem health (Garcia et al., 2001). Non-point source pollutants are mainly transported overland and through the soil by runoff (Dubus et al., 2000). These pollutants ultimately find their way into groundwater, wetlands, rivers and lakes and, finally, to oceans in the form of sediment and chemical loads carried by rivers (Albanis et al., 1998; EPA, 2003; Aydın and Köprücü, 2005). The major insecticides that are usually applied in agriculture and public healthy sections include organophosphate, organocholorines, pyrethroids and carbamate. Contamination of water by insecticides is mainly due to intensive agriculture combined with surface runoff and subsurface drainage, usually within a few weeks after application (Banaee et al., 2011) Most of insecticides have been known to be highly toxic to non-target organisms that inhabit natural environments close to agricultural fields. Several studies reported that some of surface waters 
and surrounding environments were contaminated with different insecticides (Arjmandi et al., 2010; Bagheri et al., 2000; Ghassempour et al., 2002; Rahiminezhhad et al., 2009; Tarahi Tabrizi, 2001). The continuous presences of insecticides are the consequence of application (timing, rate, frequency) and the rainfall during the application period (Lydy and Austin, 2004; U.S.A. EPA, 2005; Bouldin et al., 2007; Mast et al., 2007; Echols et al., 2008; Vryzas et al., 2009; Werimo et al., 2009; Ding et al., 2011; Hope, 2012). Although monitoring the presence of insecticides in surface water and ground water are generally poor in much of the world and especially in developing countries, the effect of these pollutants on aquatic animals' health frequently was investigated (Chambers et al., 2002; Richards and Kendall, 2002;Lam and Wu, 2003; Scott and Sloman, 2004; Cengiz, 2006; Box et al., 2007; Sun and Chen, 2008; Banaee et al., 2008; Banaee et al., 2011; Banaee and Ahmadi, 2011).

Since fishes are important sources of proteins and lipids for humans and domestic animals, so health of fishes is very important for human beings. Fish like other aquatic organisms may be exposed to a great range of insecticides during the course of their life cycle. In fish, different insecticides can be absorbed through gills, skin or alimentary ducts (Schlenk, 2005; Banaee et al., 2011; Banaee, 2012). Fishes are particularly sensitive to environmental contamination of water. Hence, pollutants such as insecticides may significantly damage certain physiological and biochemical processes when they enter into the organs of fishes (Banaee et al., 2011). So, the effects of insecticides on fishes are of great concern.

Recently, many studies have been conducted to determine the mechanisms of insecticides' damage in fishes, with the ultimate goal of monitoring, controlling and possibly intervening in xenobiotics exposure and its effects on the aquatic ecosystem. The main mechanism of action of organophosphate and carbamate insecticides is block of enzyme acetylcholinesterase action that results in signs and symptoms of intensive cholinergic stimulation. Organochlorines are neurotoxins which effect on sodium and potassium channels in neurons. Decrease of potassium permeability and inhibition of cadmodulin, $\mathrm{Na} / \mathrm{K}$ and $\mathrm{Ca}-\mathrm{ATPase}$ activity occur by organochlorine insecticides. Pyrethroids can block Na channel and effect on the function of GABA-receptors in nerve fiber. Oxidative stress is another mechanism for toxicity of insectisides resulting in cell death includescellular necrosis and apoptosis and dysfunction in cellular physiology include alterations in metabolic and vital functions of the cells.Hence, fish should be able of managing environmental exposure by detoxifying these xenobiotic. In order to do this task, fish like aerobic animals have evolved complex of detoxification system, composed of two main parts including enzymatic and non-enzymatic components. Theroles of enzymatic and non-enzymatic detoxification system of animal's body lessen the potential damages caused by the toxicity of environmental pollutants. Although it is possible that reactive oxygen species (ROS) produced during the insecticides detoxification process in liver tissue may react with vital macromolecules such as lipid, protein, carbohydrate and nucleic acid and result in oxidative damage to aquatic organisms (Üner et al., 2006). ROS derived damage to natural and structure cellular components are generally considered a serious mechanism involved in the physiological and pathological disorders (Sepici-Dinçel et al., 2009).So, much literature suggests an association between impaired detoxification and disease 
such as oxidative stress, histopathological damages, hormonal dysfunctions, reproductive disorders, immunosuppression syndrome and etc.

Hematological and biochemical studies, along with histopathology, are the major means to learn a toxicants mode of action. Hematological and clinical chemistry parameters can be detected rapidly and hence can be used for prediction and diagnosis of insecticides toxicity. Alterations in these parameters show toxic stress in the treated animals especially on blood and blood-forming organs. Alterations in blood biochemical parameters as important diagnostic tool can be used for the detection of abnormalities in the liver and other tissues (Banaee et al., 2011). This chapter describes some of the important hematological, biochemical and histopathological changes that occur in fish exposed to different insecticides. An initial description is given of the detoxification process, and then the other physiological dysfunction in various biological systems occurring in fish exposed to different insecticides will be discussed.

\section{Metabolism of insecticides}

In fish, insecticides are readily converted into more polar compounds through biotransformation and stored in the bile until their excretion. In general, detoxification process involves two phase, functionalization (phase I) and conjugation (phase II). The first biotransformation step (phase I) adds oxygen to the insecticides structure and the second step (phase II) conjugates the oxygenated product with and endogenous water-soluble small molecule present in the cell. The final products are highly water-soluble conjugates that are easier to eliminate than the parent compounds.Although, recently, anti-porter activity (p-glycoprotein or multidrug resistance) has been defined as the Phase III detoxification system, there is no exactly information about this detoxification system in fish.Classic detoxification pathways of insecticides in aquatic organisms are presented in Table 1.

\section{Phase I}

The phase I detoxification system, composed over 10 families of enzymes which played important role in the metabolism of various xenobiotic. The phase I detoxification system, composed mainly of the cytochrome P450 supergene family of enzyme, that are present in all eukaryotes and some prokaryotes and is generally the first enzymatic defense system against xenobiotic.A great diversity of cytochrome P450 enzymes in fish has been recognized (Stegeman and Hahn, 1994), and CYP1A, CYP2B, CYP2E1, CYP2K1 and CYP3A have been recently identified in liver of some freshwater fish (Nabb et al., 2006) which play an important role in the detoxification of organophosphate and carbamate insecticides (Ferrari et al., 2007). The common pathways of biotransformation of different kinds of insecticides include three cytochrome P450 (CYP) mediated reactions: O-dealkylation, hydroxylation, and epoxidation of insecticides (Keizer et al., 1995; Kitamura et al., 2000; Straus et al., 2000; Behrens \& Segner, 
2001; Nebbia, 2001). Most insecticides are metabolized through phase I biotransformation. In general, CYP450 enzymes mediated reactions by using oxygen and NADH, as a cofactor, lead to detoxification and subsequent excretion of xenobiotic. The CYP450 enzymes can also facilitate dealkylation, dearylation, aromatic ring hydroxylation, thioether oxidation, and deamination (Table 1.). However, CYP450 enzymes mediated metabolism can also cause formation of reactive metabolites which is far more dangerous than parental compounds. For example, oxidative group transfer of certain organophosphorous insecticides to the toxicorganophosphate, e.g. conversion of parathion to paraoxon,oxidative dechlorination of chloroform to phosgene,activation of ethyl carbamate to urethan. However, many of these same chemicals are also detoxified by cytochrome $\mathrm{P} 450$ by conversion to less toxic metabolites. In some cases, the same enzyme may catalyze activation and detoxification reactions for a given chemical. The resulting toxic effect of a xenobiotic chemical is thus due to a balance between metabolic activation and deactivation (Casarett and Doull, 1996).

\section{Phase II}

In phase II reactions, metabolites produced in phase I detoxification often conjugate with glutathione, uridyl-diphosphate glucose (UDPG), uridyl-diphosphate-glucuronic acid (UDPGA), amino acid derivatives and sulfate derivatives and can readily excrete from the fish body (Keizer et al., 1995; Kitamura et al., 2000; Straus et al., 2000; Behrens \& Segner, 2001; Nebbia, 2001). In fact, this results from enzymatic oxidation and hydrolysis that produce metabolites with $\mathrm{OH}, \mathrm{COOH}$ and $\mathrm{NH} 2, \mathrm{SH}$ functional groups. These functional groups are then subject to conjugation with carbohydrates, glutathione, sulfate, andamino acids, and then, the final metabolites may also be excreted from the body of fish through the skin, gills, genital products, urine as sulphated and glucuronidated metabolites and stool as glutathione conjugated metabolites (Kitamura et al., 2000; Straus et al., 2000; Behrens \& Segner, 2001; McKim \& Lein, 2001; Nebbia, 2001).

\begin{tabular}{|c|c|c|c|}
\hline Metabc & & Category & Reaction pattern \\
\hline \multirow[t]{7}{*}{ Oxidation } & Alkyl oxidation & 01 & $\mathrm{R}-\mathrm{CH}_{3} \rightarrow \mathrm{R}-\mathrm{CH}_{2} \mathrm{OH} \rightarrow \mathrm{R}-\mathrm{CHO} \rightarrow \mathrm{RCOOH}$ \\
\hline & $O(N)$-dealkylation & $\mathrm{O} 2$ & $-\mathrm{O}\{\mathrm{N}\}-\mathrm{CH}_{3} \rightarrow\left[-\mathrm{O}\{\mathrm{N}\}-\mathrm{CH}_{2} \mathrm{OH}\right] \rightarrow-\mathrm{O}\{\mathrm{N}\} \mathrm{H}$ \\
\hline & \multirow[t]{3}{*}{ Ring hydroxylation } & $\mathrm{O} 3$ & $\mathrm{Ar}-\mathrm{H} \rightarrow \mathrm{Ar}-\mathrm{OH}$ \\
\hline & & $\mathrm{O} 4$ & $\mathrm{Ar}-\mathrm{H} \rightarrow \mathrm{Ar}-(\mathrm{OH})_{2}$ \\
\hline & & O5 & Quinone \\
\hline & S-oxidation & O6 & $-\mathrm{S}-\rightarrow-\mathrm{S}(\mathrm{O})-\rightarrow-\mathrm{S}\left(\mathrm{O}_{2}\right)-$ \\
\hline & Desulfuration & $\mathrm{O} 7$ & $\mathrm{P}=\mathrm{S} \rightarrow \mathrm{P}=\mathrm{O}, \mathrm{C}-\mathrm{SO}_{3} \mathrm{H} \rightarrow \mathrm{C}-\mathrm{OH}$ \\
\hline
\end{tabular}




\begin{tabular}{|c|c|c|c|}
\hline Metabolism & & Category & Reaction pattern \\
\hline & Others & O8 & $\begin{array}{l}\mathrm{C}=\mathrm{C} \rightarrow \text { epoxide, ketone, } \mathrm{NH}_{2} \rightarrow \mathrm{NHOH} \\
\rightarrow \mathrm{NO}, \mathrm{R}-\mathrm{X} \rightarrow \mathrm{R}-\mathrm{OH}\left[\mathrm{X}=\mathrm{NO}_{2}\right]\end{array}$ \\
\hline \multicolumn{4}{|l|}{ Reduction } \\
\hline & Dehalogenation & R1 & $\mathrm{RX} \rightarrow \mathrm{R}-\mathrm{H}+\mathrm{X}[\mathrm{X}=$ halogen $]$ \\
\hline & Dehydrohalogenation & $\mathrm{R} 2$ & $\mathrm{CH}-\mathrm{CX} \rightarrow \mathrm{C}=\mathrm{C}+\mathrm{HX}[\mathrm{X}=$ halogen $]$ \\
\hline & Nitro group & R3 & $-\mathrm{NO}_{2} \rightarrow[-\mathrm{NO}] \rightarrow \mathrm{NHOH} \rightarrow \mathrm{NH}_{2}$ \\
\hline & Multiple bond & R4 & $-\mathrm{N}=\mathrm{N}-\rightarrow-\mathrm{NH}-\mathrm{NH}-, \quad-\mathrm{C} \equiv \mathrm{C}-\rightarrow-\mathrm{C}=\mathrm{C}-\rightarrow-\mathrm{CH}-\mathrm{CH}$ \\
\hline & Sulfone, sulfoxide & R5 & $-\mathrm{S}\left(\mathrm{O}_{2}\right)-\rightarrow-\mathrm{S}(\mathrm{O})-\rightarrow-\mathrm{S}-$ Hydrolysis \\
\hline & Carboxyl ester & $\mathrm{H} 1$ & $-\mathrm{C}(=\mathrm{O}) \mathrm{OR} \rightarrow \mathrm{COOH}+\mathrm{R}-\mathrm{OH}$ \\
\hline & & & $-\mathrm{P}(=\mathrm{X})-\mathrm{YR} \rightarrow-\mathrm{P}(=\mathrm{X})-\mathrm{OH}+\mathrm{RYH}$ \\
\hline & Phosphoryl (sulfonyl) ester & $\mathrm{H} 2$ & {$[X, Y=O, S]$} \\
\hline & & & $\mathrm{ROS}(=\mathrm{O}) \mathrm{OR}^{\prime} \rightarrow \mathrm{ROH}+\mathrm{R}^{\prime} \mathrm{SO}_{3} \mathrm{H}$ \\
\hline & Amide & $\mathrm{H} 3$ & $-\mathrm{C}(=\mathrm{O}) \mathrm{NR}-\rightarrow-\mathrm{COOH}+\mathrm{NHR}$ \\
\hline & Carbamate & $\mathrm{H} 4$ & $-\mathrm{NC}(=\mathrm{O}) \mathrm{O}($ or $\mathrm{S}) \mathrm{R}-\rightarrow-\mathrm{NH}+\mathrm{RO}($ or $\mathrm{S}) \mathrm{H}$ \\
\hline & Urea & H5 & $-\mathrm{NHC}(=\mathrm{O}) \mathrm{NR}-\rightarrow-\mathrm{NH}_{2}+\mathrm{RNH}-$ \\
\hline & Others & $\mathrm{H} 6$ & $\begin{array}{l}-\mathrm{CN} \rightarrow-\mathrm{CONH}_{2} \rightarrow-\mathrm{COOH}, \quad \mathrm{R}-\mathrm{X} \rightarrow \mathrm{R}-\mathrm{OH} \\
{[\mathrm{X}=\text { halogen }]}\end{array}$ \\
\hline \multicolumn{4}{|l|}{ Conjugation } \\
\hline & Glucuronidation & $\mathrm{C} 1$ & $\mathrm{R}-\mathrm{XH} \rightarrow \mathrm{R}-\mathrm{X}-\mathrm{Gla}[\mathrm{X}=\mathrm{O}, \mathrm{COO}, \mathrm{S}, \mathrm{NH}]$ \\
\hline & Glucosidation & $\mathrm{C} 2$ & $\begin{array}{l}R-X H \rightarrow R-X-G l u \rightarrow R-X-\left(6 O-R^{\prime}\right) G l u \\
{\left[X=O, C O O, S, N H ; R^{\prime}=\text { acetyl, malonyl, pentosyl }\right]}\end{array}$ \\
\hline & Sulfation & $\mathrm{C} 3$ & $\mathrm{R}-\mathrm{X}-\mathrm{H} \rightarrow \mathrm{R}-\mathrm{X}-\mathrm{SO}_{3} \mathrm{H}[\mathrm{X}=\mathrm{O}, \mathrm{NH}]$ \\
\hline & Glutathione conjugation & C4 & $\begin{array}{l}R-X+G S H \rightarrow R-S G \rightarrow R-\text { Cys - Gly } \\
\rightarrow R-\text { Cys } \rightarrow R-(N-\text { acetyl - Cys) }\end{array}$ \\
\hline & $N$-acylation & C5 & $-\mathrm{NH}_{2} \rightarrow-\mathrm{NHCHO},-\mathrm{NHC}(=\mathrm{O}) \mathrm{CH}_{3}$ \\
\hline & Amino acid conjugation & C6 & $\mathrm{R}-\mathrm{COOH} \rightarrow \mathrm{RC}(=\mathrm{O}) \mathrm{NHC}\left(\mathrm{R}^{\prime}\right) \mathrm{COOH}$ \\
\hline & Methylation & $\mathrm{C7}$ & $\mathrm{R}-\mathrm{O}($ or $\mathrm{NH}) \mathrm{H} \rightarrow \mathrm{R}-\mathrm{O}($ or $\mathrm{NH}) \mathrm{CH}_{3}$ \\
\hline Miscellaneous & & M & Isomerization, rearrangement, etc. \\
\hline
\end{tabular}

Table 1. Classic detoxification pathways of insecticides in aquatic organisms (adapted from Katagi, 2010) 


\section{Physiological dysfunction in various biological systems of fish by insecticides}

\subsection{Behavioral response}

Behavioral alterations and the change of body's color pattern of fish or darkness of skin and mucosa increase to the skin and gill surface, as well as bleeding around the eyeball and the base of pectoral fins and also, the volume increase of the liver and the gall bladder in fish exposed to insecticides were the main symptoms evidenced in the toxicology studies.

Behavioral changes are the most sensitive indicators of potential toxic effects. Most insecticides affect the behavioral patterns of fish by interfering with the nervous systems and sensory receptors and consequently it can lead to disorders in the fish response to environmental stimuli. The effect of certain insecticides on the activity of acetylcholinestrase may also lead to a decreased mobility in fish (Banaee, 2012). Several studies have demonstrated that insecticides are metabolized in liver to toxic derivate via cytochrome P450 mono oxygenases (Fujii and Asaka, 1982; Hamm et al., 2001; Schlenk, 2005) and finally, these metabolites were hydrolyzed in microsomes (Keizer et al., 1993; Keizer et al., 1995) and excreted from the body. Nevertheless, rainbow trout was very sensitive to organophosphate insecticides toxicity due to a lack of esterase activity and a very sensitive acetylcholinesterase activity to OPs inhibition (Keizer et al., 1995). The phosphorus group of organophosphate insecticides attacks the hydroxyl group of the serine amino acid at the active site of acetylcholinesterase inhibiting the enzyme (Üner et al., 2006; Banaee et al., 2011). Inhibition of AChE in fish was accompanied by an increase in acetylcholine levels (Üner et al., 2006; Banaee, 2012) that can be dangerous since it will impact feeding capability, swimming activity, identification, and spatial orientation of the species (Banaee et al., 2008; Banaee et al., 2011). Thus, AChE inhibition is considered to be a specific biomarker of exposure to organophosphorus and carbamate insecticides like diazinon, chlorpyrifos, propoxur, isoprocarb, (Üner et al., 2006; Cong et al., 2008; 2009; Wang et al., 2009; Banaee et al., 2011;). Similar results have been observed for pyrethroids insecticide toxicity (Koprucu et al., 2006). Disorder in $\gamma$-aminobutyrate (GABA) system in brain of rainbow trout exposed to sub-lethal lindane was reported by Aldegunde et al., (1999). GABA receptors inhibit the transmission of nerve impulses; thus disturbances in this receptor would also lead to an over stimulation of the nerves. Researchers have reported the same alterations in Oryzias latipes, Cyprinus carpio, Labeo rohita, Oncorhynchus tshawytscha, O.latipes, Cirrhinus mrigala, Oreochromis niloticus, Clarias gariepinus treated with chlorpyrifos (Rice et al., 1997; Halappa \& David, 2009), malathion (Patil \& David, 2008), diazinon (Scholz et al., 2000), endosulfan (Gormley \& Teather, 2003), Fenvalerate (Mushigeri \& David, 2005), fenitrothion (Benli \& Özkul, 2010), dimethoate (Auta et al., 2002), respectively.

\section{Oxidative stress}

During the detoxification process, ROS are produced (Üner et al., 2006; Isik and Celik, 2008) and they can indiscriminately attack and damage cellular macromolecules -lipids, proteins 
and DNA- in living cells resulting in serious disturbances in physiological cell processes (Sureda et al., 2006; Tejada et al., 2007). Li et al. (2010c, d; 2011b) believed that cellular antioxidant responses could be used as potential biomarkers for monitoring residual xenobiotic present in aquatic environment. For example, Salvo et al. (2012) found that endosulfan at the sub-lethal concentration in subchronic exposure caused significant changes in liver somatic indices as well as induction of the phase I biotransformation system and oxidative stress in juvenile common carp (Cyprinus carpio). Similar results was observed in gar (Atractosteus tropicus), Tilapia (Oreochromis niloticus), tropical reef fish (Acanthochromis polyacanthus) exposed to ethorophos (Mena Torres et al., 2012), lamba-cyhalothrin (Piner and Uner, 2012), Chlorpyrifos, respectively (Botte et al., 2011; Xing et al., 2011; Oruc, 2012).

The antioxidant enzymes that provide the first line of cellular defense to ROS include superoxide dismutase (SOD), catalase (CAT), glutathione peroxidase (GPx) and glutathione reductase (GR), glutathione $S$-transferease (GST) and xanthine oxidase (XOD), etc. However, an imbalance between the activities of cellular antioxidant enzymes and ROS production results in oxidative stress and cellular damage. If the antioxidant system is not able to eliminate or neutralize the excess of ROS, there is an increased risk of oxidative damage (Üneret al., 2006; Oruç and Usta, 2007; Isik and Celik, 2008). It is well established that waterborne pollutants induces oxidative stress and cellular damage in affected aquatic organisms (Sureda et al., 2006; Box et al., 2007).

GR plays a vital role in recycling oxidized glutathione (GSSG) to reduced glutathione (GSH) (Jos et al., 2005; Box et al., 2007; Sureda et al., 2009). GR plays an important role in diazinon detoxification because diazinon can be directly conjugated with GSH facilitating the excretion from the animal body (Banaee et al., 2012). GSH also participates in neutralizing free radicals (Jos et al., 2005; Sureda et al., 2009). This GSH consumption leads to an increase in GR activity in order to recycle GSH. The increase in GR activity observed after seven days of exposure to sub-lethal concentrations of diazinon was followed by a declining trend, which is clearly manifested after 28 days of diazinon contact (Banaee et al., 2012). These results agree with a previous study carried out on fishes that had been exposed to environmental pollutants (Franco et al., 2008). Banaee et al., (2012) found that the decreased activity of GR at the $28^{\text {th }}$ day after an initial antioxidant response may be indicative of a disorder in cell metabolism. GR activity is severely dependent on cellular NADPH levels (Peña-Llopis et al., 2003). It has been reported that the contact with pesticides decreased the synthesis and accelerated the breakdown of GR mediated by a disorder in NADPH synthesis and decreased activity of glucose-6-phosphate dehydrogenase (G6PDH) enzyme (Ozmen et al., 2004; Li et al., 2010c).

Since an increase of GPx activity is necessary to eliminate the excess of $\mathrm{H}_{2} \mathrm{O}_{2}$ and lipid hydroperoxides produced in hepatocytes of fishes exposed to. The increased activity of GPx accelerates the utilization of GSHto GSSG. This increased GSSG, indicative of a more oxidized state, may explain the decreased levels of total antioxidant capacity in liver cells of fish after exposure to pesticide. A decrease in GPx activity to basal values is probably related to decreasing cellular GSH levels on the days 14 and 28, although it cannot be discarded a direct effect of diazinon on the biosynthesis of the enzyme. Similar alterations in GPx activity were observed in different tissues of C. carpio exposed to diazinon (Oruç and Usta, 2007). Decreased 
GPx activity in gills, muscle, liver and brain of treated fishes with parathion were also reported, by Monterio et al. (2006).

The SOD enzymes are enzymes that catalyse the dismutation of superoxide into hydrogen peroxide and oxygen whereas CAT catalyzes the decomposition of hydrogen peroxide to water and oxygen. The increased SOD and CAT activities in hepatocytes of fishes exposed to diazinonmight be biochemical responses to over production of superoxide radicals and $\mathrm{H}_{2} \mathrm{O}_{2}$ in hepatocytes, respectively (Banaee et al., 2012). It has been shown that the CAT activity may be related to $\mathrm{H}_{2} \mathrm{O}_{2}$ production in a xenobiotic detoxification process (Achuba and Osakwe, 2003; Monterio et al., 2006). A previous study by Monterio et al., (2006) reported similar changes in the hepatic CAT activity of freshwater fish, Brycon cephalus exposed to methy parathion. Following 2-cholrophenol exposure, alterations in SOD and CAT activities in Carassius auratus were reported (Luo et al., 2006). Hai et al, (1997), and Box et al, (2007) showed that organophosphate pesticide and exposure to environmental pollutants caused a significant reduction in CAT activities in different tissues of Ictalurus nebulosus and Mytilu sgalloprovincialis, respectively. Whereas, Isik and Celik, (2008) reported in rainbow trout exposed to diazinon and methyl parathion a decrease in SOD activities in liver, gills and muscle tissues separately.

Banaee et al., (2012) found that the levels of total antioxidant capacity in hepatocytes of fishes exposed to both concentrations of diazinon were significantly decreased. Similar results were observed in carps exposed to sub-lethal concentrations of cyfluthrin (Sepici-Dinçel et al., 2009). The overproduction of free radicals during pesticide detoxification may be associated with the decrease in the hepatic total antioxidant capacity (Monterio et al., 2006). Impairment in the synthesis of enzymatic and non-enzymatic antioxidant may be the most important factor in reducing levels of cellular total antioxidant. Therefore, the decline in the hepatic total antioxidant levels make the fish cells more vulnerable to oxidative stress damage.

Glutathione S-transferases (GSTs), a family of cytosolic multifunctional enzymes, are detoxifying enzymes that are present in different tissues of fish. They catalyze the conjugation of glutathione with a variety of reactive electrophilic compounds, thereby neutralizing their active electrophilic sites and subsequently making the parent compound more water soluble. For example, the toxicity of diazinon can be decreased by the action of carboxylesterase enzyme which catalyses the hydrolytic degeneration of diazinon and by the action of glutathione Stransferase which catalyses the formation of excrete-able conjugate (Keizer et al., 1995). In addition to catalytic functions, the GSTs can also bind covalently/non-covalently to a wide number of hydrophobic compounds, such as insecticides.

Thioltransferase catalyzes the reversible thiol-disulfide interchange reactions. The enzyme has a major role in maintaining intracellular thiol in the reduced state and functions in this capacity by coupling to glutathione and glutathione reductase. Thioltransferase also has a role in the cellular regulation by catalyzing the reversible modification of proteins by thiol-disulfide interchange (Bernstein et al., 1982).

Xanthine oxidase (XOD) is an essential enzyme that converts hypoxanthine to xanthine, subsequent to uric acid. This enzyme contains FAD, molybdenum and Iron are exclusively 
found in liver, intestine and little amount in other tissues of animals (Sathyanarayana, 2005) also stated XOD played a vital role in transformation of toxic ammonia into nontoxic uric acid. Xanthine oxidase produces hydrogen peroxide which is very dangerous to the animal, and then it converts into $\mathrm{HO}$ and $\mathrm{O}_{2}$. Further, the uric acid may act as an antioxidant and free radical scavenger protects the cells from oxidative damage (Sheehan et al., 2001; Guskovet al., 2002). Naveed and Janaiah (2011) reported that the reduction in XOD activity in liver of fish, Channa punctatus exposed to triazophos leads to increase in cellular damage and may be due to nonavailability of Iron to the fish during toxic period.

\section{Hematological parameters}

The main hematological parameters in fish including red blood cell counts (RBC), hematocrit $(\mathrm{Ht})$, hemoglobin $(\mathrm{Hb})$, mean corpuscular volume $(\mathrm{MCV})$, mean corpuscular hemoglobin $(\mathrm{MCH})$ and mean corpuscular hemoglobin concentration (MCHC) may be influenced by intrinsic and externalfactors. Toxicology studies show that the disruptive action of different insecticides on the erythropoietic tissue such as kidney and spleen may decrease erythrocyte number and hemoglobin content as an anemic sign, and even lead to death of fish. A low red cell or hemoglobin count indicates anemia, or severe bleeding. Low hemoglobin usually means the animal has anemia. Anemia results from conditions that decrease the number or size of red cells, such as excessive bleeding, a dietary deficiency, destruction of cells because of a transfusion reaction or mechanical heart valve, or abnormality formed hemoglobin (Hisa and Connie, 1998). Decreases in the number or size of red cells also decrease the amount of space they occupy, resulting in a lower hematocrit. A low hematocit, combined with abnormal blood tests, confirms the diagnosis. Decreased erythrocyte count and haemoglobin content in freshwater fish Channa punctatus, (Anees, 1978) and Cyprinus carpio (Svoboda,et al., 2001; Banaee et al., 2008) after acute and sub-lethal exposure to diazinon.

Another type of hematological response to the effect of organophosphrous compounds was a significant increment of mean corpuscular volume (MCV) associated with increase of hematocrit value and drop of MCHC. MCV is the index most often used. It measures the average volume of red blood cell by dividing the hematocrit by RBC. The MCV categorizes red blood cells by size. Under a microscope, stained red blood cells with a high MCV appear larger than cells with a normal or low MCV. Mean corpuscular hemoglobin (MCH) measures the average amount of hemoglobin within a red cell. A similar measurement, mean corpuscular hemoglobin concentration (MCHC), expresses the average concentration of hemoglobin in the red blood cells. In contrary, values of $\mathrm{MCV}, \mathrm{MCH}$ and $\mathrm{MCHC}$ registered in during exposure to diazinon based pesticide in 60 and $120 \mu \mathrm{g} / \mathrm{L}$ concentrations to common carp were comparable with the control group (Banaee et al., 2008). Alteration in values of MCV, MCH and MCHC in Cyprinus carpio was reported (Svoboda et al., 2001).

The white blood cell (WBC) count determines the total number of white cells (leukocytes) in bloodsample. Fewer in number than the red cells, WBC are the body's primary means of fighting infection. There are five main types of white cells (lymphocytes, monocytes, neutrophil, eosinophiland basophiles), each of which plays a different role in responding to 
presence of foreign organisms in the body. The number of white blood cells may increase or decrease significantly in certain diseases. Banaee et al., (2008) observed significant decrease of leukocyte count of common carp in during exposure to sub-lethal concentration of diazinon. A low white blood cell count may mean dysfunction in hematological tissues (spleen and kidney) or certain infectious diseases. Lower than normal levels of lymphocytes (lymphopenia) can be an indicator of immune system deficiency.

Poisonous substances treatments can also deplete the body's supply of lymphocytes, as can exposure to diazinon. Lymphopenia as a consequence of methy-parathion based pesticide was reported by Nath and Banerjee (1996) in Heteropneustes fossilis and also by Siwicki et al., (1990) in common carp after an acute effect of trichlorfon.

Decreased in lymphocyte and monocyte percentage in smear were showed in Cyprinus carpio (Svoboda et al., 2001). In contrary, Banaee et al., (2008) observed significant increment of neutrophil percentage in smear of common carp in during exposure to 60 and $120 \mu \mathrm{g} / \mathrm{L}$ concentration of diazinon. The most common and important cause of neutrophilia is infection, and most infections cause neutrophilia. The degree of elevation often indicates the severity of the infection. Tissue damage from other causes raises the neutrophile for similar reasons. Poisonings, and severe disease, like kidney failure all cause neutrophilia (Holland et al., 1997). Ghosh and Banerjee (1993) reported lymphopenia and increased in both neutrophil and eosinophil in Heteropneustes fossilis, after an effect of dimethoate in $96 \mathrm{~h} \mathrm{LC}_{50}$ concentration.

\section{Blood biochemical parameters}

Measurement of blood biochemical parameters are used as important diagnostic tool for the detection of abnormalities in the liver and other tissues (Banaee et al., 2011). Liver serves to protect the body from potentially harmful ingredients absorbed from the intestinal tract, gills, and skin as well as toxic by-products of metabolism by various mechanisms that previously described.

The significant differences in glucose concentrations in plasma between the control and treatment fish, following the action of different insecticides, which may be considered to be the manifestation of stress (Banaee et al., 2011). In agreement with our results, Ceron, et al., (1997) report significant glucose increase in common eel (Anguilla anguilla) following a $96 \mathrm{~h}$ action of sub-lethal concentrations of diazinon. Bhatia et al., (1972) and Weiss et al., (1984) reported a pronounced increase in blood sugar level which was going parallel to the inhibition of the cholinesterase and the appearance of manifestation of cholinergic stimulation as a result of parathion intoxication.

Glucose increase is a general response of fish to acute pollutant effects, including organophosphates insecticides (Banaee, 2012). Plasma glucose was elevated in treated silver catfish Rhamdia quelen after all periods of clomazone exposure (Lazzari, et al., 2006).

Albumin and globulin make up most of the protein within the body and are measured in the total protein of the plasma. Total protein, albumin and globulin tests are used to monitor the 
course of diseases in immune disorders, liver dysfunction and impaired kidney activity (Banaee et al., 2011). According to the test results, levels of total protein, albumin and globulin were decreased in fish exposed to diazinon. Decreased total protein levels may be due to starvation, malnutrition and chronic liver diseases (Banaee et al., 2011). Other authors also found that the levels of total protein and albumin are decreased in the fish exposed to different pollutants and insecticides (Vijayan et al., 1997; Velisek et al., 2009).

Decreased globulin levels have been reported in immune deficiency. In fact, the effect of diazinon on the immune system of tilapia (Oreochromis niloticus) and beluga sturgeon (Huso huso) as immunomodulator has been studied by other authors (Khoshbavar-Rostami et al., 2006; Gokcimen et al., 2007). Diazinon-induced tissue destruction and hepatocyte apoptosis might be the most important agent responsible of reducing the synthesis of total protein, albumin, and immunoglobulin by the liver (Gokcimen et al., 2007).

Aspartate aminotransferase (AST) and alanine aminotransferase (ALT) are found in the liver, heart, skeletal muscle, kidney, pancreas, spleen, erythrocyte, brain and gills (Banaee et al., 2011). When diseases or injuries affect these tissues, the cells are destroyed and these enzymes are released into plasma. Keizer et al (1995) showed that diazinon in fish liver can be metabolized to diazoxon and other metabolites including pyrimidinol by cytochrome P450 monoxygenase and during this process, reactive oxygen species (ROS) are generated. The increase in intracellular levels of ROS may lead to lipid peroxidation resulting in an increased permeability of liver cell membrane. As a result, liver enzymes including AST and ALT are released into plasma. Similarly, ROS produced from the metabolism of diazinon may damage other tissues such as gills, muscle, heart, kidney and spleen causing the leakage of enzymes into plasma. In this sense, if the cellular injury is chronic AST and ALT levels will remain elevated (Banaee et al., 2011). Increased activities of AST and ALT were observed in plasma of Channa punctatus(Agrahari et al., 2007) exposed to organophosphorus insecticides. Banaee et al., (2008) have reported increased levels of AST and ALT followed by the exposure of common carp to diazinon.

Lactate dehydrogenase (LDH) is an enzyme found in almost all body tissues, such as heart, kidneys, liver, skeletal muscle, brain, erythrocyte and gills (Banaee et al., 2011). LDH measurement is used to detect tissue disorders and as an aid in the diagnosis of tissue damage (Banaee et al., 2011). Although a significant decrease in LDH content in plasma was observed in fish exposed to diazinon on 7th day, LDH activity was not significantly reduced on 14th and 28th days. Our data on 7 days after initial experiment are in accordance with several reports that revealed decreased LDH activity in tissues under various pesticide toxicity conditions in different fishes such as O. mossambicus (Saha and Kaviraj, 2009) and C. punctatus (Agrahari et al., 2007). Hernández et al. (2006) reported some insecticides, such as organophosphates are able to cause inhibition of LDH activity. However, the recovery evidenced on 14th and 28th days in LDH activity could indicate that diazinon concentration used in the present study was not enough to produce chronic LDH alterations (Banaee et al., 2011).

Creatine kinase (CK) is an enzyme found in muscle, heart, gills and brain (Banaee et al., 2011). Although, fish exposed to higher dose of diazinon exhibited higher CK activities in plasma on 7th day, plasma CK concentrations resumed to its normal levels or even a reduced activity on 
14th and 28th day. However, elevated levels of this enzyme in plasma indicate a transient damage to either muscle fibers or other tissues. Previous results reported that continuous exposure to acute pesticide (bifenthrin) concentrations resulted in significantly increased levels of CK in common carp at $96 \mathrm{~h}$ (Velisek et al., 2008).

Creatinine is a breakdown product of CK in muscle. The creatinine test has been usually used to diagnose impaired kidney function and to detect renal damage (Toffaletti and McDonnell, 2008; Banaee et al., 2011) However, the lack of changes in creatinine levels are in accordance with the previous results obtained by Gilbert et al (1989) and Banaee et al. (2011) which reported that plasma creatinine was usually not an accurate biomarker to distinguish dysfunction in kidney tissue. The creatinine test has been usually used to diagnose impaired kidney function and to detect renal damage (Toffaletti and McDonnell, 2008).

The alkaline phosphatase (ALP) plays a significant role in phosphate hydrolysis and in membrane transport as well as is a good bio-indicator of stress in biological systems. The importance of measuring alkaline phosphatase is to check the liver dysfunction (Banaee et al., 2011) and the cellular membrane health. Alkaline phosphatase (ALP) is an enzyme found in different body tissues; in liver, is produced by the cells lining the small bile ducts (Agrahari et al., 2007). Increased activity of ALP in blood plasma on 14th day may be related to hepatic tissue damage and dysfunction due to pesticide toxicity; the elevation in ALP activity on may be due to an increase in transphosphorylation activity (Sharma, 1990). Agrahari et al. (2007) found increased levels of ALP in plasma of Channa punctatus exposed to monocrotophos. These changes in ALP activities in plasma were earlier reported in tilapia (Rao, 2006) and in common carp (Banaee et al., 2008). The return of ALP activity to basal values could indicate a fish adaptation to the diazinon treatment at sub-lethal concentrations.

Acid phosphatase plays an important role in carbohydrate metabolism. This enzyme can be found inside the membrane of lysosomes. So, any damage to the membrane of lysosomes can cause the release of this enzyme into muscle and increase its levels.

\section{Immune system}

The immune system of fish is important for defense against a variety of pathogens. The system is very sensitive to homeostatic adjustments via endocrine regulation and is influenced by the biochemical status of the nervous system. Thus, any impairment in the nervous system and disturbance in the biochemical homeostasis can weaken the immune system of fish.

Different insecticides at sub-lethal levels have been recognized as stressors causing immune-suppression in fish (Werner and Oram, 2008). In addition, some insecticides may exert immunotoxic effects by altering the transcription of important mediators of the fish immune system (Eder et al., 2009). Effects of insecticides like P,P'-DDE, lindane, cypermethrin, chlorpyrifos, diazinon on the immune factors of fish such as Interleukin- $1 \beta$ (IL-1 $\beta$ ), IL-1 $\beta$ receptor (IL-1R1), Interferon gamma (IFN- $\gamma 2 b), \mathrm{TNF} \alpha, \mathrm{MHCI} \alpha, \mathrm{MHCII} \alpha$, Mx, TLR9, I $\gamma \mathrm{ML}$ and C- reactive protein (CRP), TCR $\alpha$ in head- kidney leucocytes, Lyso- 
zyme activity, chemiluminuscence (CL) response and immunocompetent cells population size, IgM levels, value of white blood cells (WBC) and respiratory burst activity, head kidney phagocytes and peripheral blood leucocytes, etc., have been reported by scholars (Betoulle et al., 2000; Khoshbavar-Rostami et al., 2006; Banaee et al., 2008; Cuesta et al., 2008; Girón-Pérez et al., 2009; Shelley et al., 2009; Ahmadi et al., 2011; Jin et al., 2011, Wang et al., 2011). The exposure to sub-lethal concentrations of insecticides is what probably makes fish vulnerable to infectious diseases because of their immune-depressiveeffects (Zelikoff et al., 2000). For example, the susceptibility of juvenile chinoock salmon (O.tshawytscha) to infectious hematopoietic necrosis virus was significantly increased in fish exposed to sub-lethal concentrations of esfenvalerate (Clifford et al., 2005). Similar results were reported in goldfish and common carp that were exposed to carbaryl and lindane respectively (Shea, 1983; Shea \& Berry, 1984; Cossarini-dunier\&Hattenberger, 1988).

Lysozymes are a family of enzymes with antibacterial activity characterized by the ability to damage the cell wall of bacteria. Ahmadi et al. (2011) found that exposure to diazinon induced a dose-dependent decrease in rainbow trout plasma lysozyme activity. Peroxidases are a large family of enzymes which play important role as natural antibacterial agent in animal immune system, e.g., myeloperoxidase (Clark and Klebanoff 1975). Ahmadi et al. (2011) indicated that diazinon treatment of rainbow trout significantly affected the peroxidase activity.

Globulin is made up of subunit of $\alpha 1, \alpha 2, \beta$, and $\gamma$ globulins, which are considered as the source of almost all the immunologically active proteins in the blood (Jha et al., 2007; Ahmadi et al., 2012).Decreased globulin levels have been reported in immune deficiency. In fact, the effect of diazinon on the immune system of tilapia (Oreochromis niloticus) and beluga sturgeon (Huso huso) as immunomodulator has been studied by other authors (Khoshbavar-Rostami et al., 2006). Significant decrease in globulins levels in plasma of fish exposed to diazinon could be due to a disruption in protein biosynthesis (Ahmadi et al., 2011). In the other word, diazinoninduced tissue destruction and hepatocyte apoptosis might be the most important agent responsible of reducing the synthesis of total protein, albumin, and immunoglobulin by the liver (Banaee et al., 2011)

Complement includes over 20 different plasma proteins that are produced by a variety of cells including, hepatocytes, macrophages, and gut epithelial cells. Some complement proteins bind to immunoglobulins or to membrane components of cells. The complement system is an essential and effective part of the innate immune system. It can rapidly distinguish and opsonize bacteria for phagocytosis by specialized phagocytes or destroy them directly by membrane disorder (Rooijakkers and van Strijp 2007; Ahmadi et al., 2012). Ahmadi et al. (2011) believed that significant depression of complement levels clearly indicated the comprehensive effects of diazinon on immune system of rainbow trout. Thus, insecticides may alter the function of the immune system and result in immune-depression, uncontrolled cell proliferation, and alterations of the host defense mechanisms including innate immunity and acquire immunity against pathogens. 


\section{Metabolism and growth}

The change from anabolic to catabolic processes in fish exposed to various insecticides involves important alterations in intermediary metabolism and has important consequences for somatic growth. Changing levels of stress hormones - catecholamine and corticosteroids -, alterations in the ability of digestive enzyme biosynthesis and behavioral changes - hunter and forage behavior - are main factors influencing on the metabolism and growth of fish. For example, histopathological damage to liver, pancreas or hepato-pancreas and intestine can also reduce efficiency of food digestion in fish. Because, these tissues have critical role in regulation biochemical parameters, especially proteins, lipids and carbohydrates, hormones as well as in synthesis and secretion of digestive enzymes, are a target organs for toxicity of insecticides. So, the effect of insecticides on these organs can change metabolism of proteins, lipids and carbohydrates. The purpose of this section of the chapter is to describe briefly the metabolic activity known to be sensitive to various forms of insecticides toxicity. However, it has refused to more descriptions, because of breadth of the topic.

The most important factors decreasing fish growth consist of disorder in feeding behaviors, decrease in feeding rate, dysfunction in metabolism process and waste of energy to overcome the stress caused by insecticide exposure (Tripathi et al., 2003). For example, disorder in the metabolism of carbohydrates, proteins and lipids in various tissues, particularly liver of fish exposed to insecticides, may reduce their growth rates. Begum (2004) found out that protein and carbohydrate metabolism in the liver and muscle tissue is disrupted on the exposure to a carbofuran insecticide. In addition, exposure during embryonic or larval stage can result in behavioral abnormalities, such as decreased ability to capture prey after hatching, functional deficiencies or slowing of growth and finally death (Kuster, 2005; Viant et al., 2006; Arufe et al., 2007). These changes were observed in larvae and embryo of zebra fish (Danio rerio) in contact with endosulfan (Velasco-Santamaria et al., 2011), beta-cyprmethrin (Xu et al., 2010); paraoxon-methyl (Küster, 2005) and sevin (Todd and Leeuwen, 2002).

\section{Carbohydrate metabolism}

Most researchers have reported that the increased blood glucose is usually observed in fish under undesirable conditions and it helps the animal by providing energy substrates to vital organs to cope with the increased energy demand (Banaee et al., 2008; Banaee et al., 2011). Elevation of blood glucose levels was widely used as a secondary marker of a stress response (Toal et al., 2004). On the basis of our literature review it is clear that insecticides can be acted as a stressor in fish. Because, hyperglycemia has been reported in many fish exposed to different insecticides. For example, increases in blood glucose levels have been reported in Heteropneustes fossilis(Saha and Kaviraj, 2009) and Cyprinus carpio (Banaee et al., 2008), O.mykiss (Banaee et al., 2011) after exposure to cypermethrin and diazinon, respectively.

Glycogenesis, glycogenolysis, glycolysis and gluconeogenesis are processes that play important roles in regulating blood glucose and carbohydrate metabolism. Glycogenesis is the 
process of glycogen synthesis from glucose molecules, in which various enzymes such as involved. Hexokinase (HK), glucokinase, and glycogen synthase are key enzyme in the glycogenesis process. Studies show that interfere with activity of these enzymes associated with insecticides exposure of organisms can inhibit glycogen stored in liver (Rezg et al., 2006). Reduced glycogen contents in live and muscle of fish have been reported by some authors.

Glycogenolysis is the catabolism of glycogen which leads to breakdown of glycogen to glucose and catalyzed by enzymes glycogen phosphorylase (GP), phosphoglucomutase (PGM), and glucose 6-phosphotase. Depletion of glycogen content in liver and muscle of fish during exposure to organophosphate insecticides was reported by many researchers (Ghosh, 1987; Nemcsok et al., 1987; Husain and Ansari, 1988).

In fish, catecholamine and corticosteroid hormones have an important role to promote gluconeogenesis. Cortisol is possible through increased levels activity of liver enzyme such as aspartate aminotransferase (AST), alanine aminotransferase (ALT) and tyrosine aminotransferase (TAT) have a stimulatory effect on gluconeogenic mechanism.Since in the gluconeogenesis process, glucose is produced from otherorganic molecules like pyruvate, lactate, glycerol, and aminoacids; elevated liver enzyme activity have an important role in the progress of the gluconeogenesis process. Although, pyruvate carboxylase, phosphoenolpyruvatecarboxykinase (PEPCK), fructose 1,6bis-phosphatase, andglucose-6-phosphatase are key enzymes of this process, there are a limit information about their activities in the gluconeogenesis process in fish exposed to insecticides.

Glycolysis is a cascade of biochemical reactions by which a molecule of glucose is oxidized to two molecules of pyruvic acid and two high energy electron carrying molecules of NADH. Glycolysis can occur with or without oxygen. In the presence of oxygen, glycolysis is the first stage of cellular respiration. Without oxygen, glycolysis allows cells to make small amounts of ATP. Glycolysis is catalyzed by enzymes such as HK, phosphor-fructokinase (PFK), and lactate dehydrogenase (LDH).

$\mathrm{LDH}$ is an enzyme participated in anaerobic pathway of carbohydrate metabolism. The increase of LDH activity is a diagnostic index widely used to recognize increases of anaerobic metabolism resulting from depletion of energy under anaerobic and environmental stress conditions. The increase of LDH activity can be attributed to the conversion of accumulated pyruvate into lactate which is transported through muscle to hepatopancreas and regenerated glucose and glycogen to supply energy fish exposed to insecticides. In other words, the increase of LDH activity in liver and muscle reflects a possible improvement in tissue glycolytic capacity.

\section{Protein metabolism}

Proteins are vital ingredient involved in the architecture of the cell, which is the main source of amino acids for building up of new tissues and for the synthesis of biologically important molecules such as enzymes, hormones, etc as well as the source of energy for fish. Alterations 
in protein content of various tissues of fish exposed to different concentrations of insecticides are linked through a biochemical metabolic pathway. For example, Bose et al. (2011) reported the increase in the protein level in liver of freshwater fish (Oreochromis niloticus) was maybe due to check the influence of thiamethoxam and effort to recover from the stress of insecticide at lower doses. They found when the concentration of thiamethoxam was increased; there was decrease in liver protein level. Thus, reduce a significant portion of protein in different tissues, especially the liver, may have been due to their degradation and possible utilization for metabolic purposes. Increases in free amino acid levels were the result of breakdown of protein for energy and impaired incorporation of amino acids in protein synthesis. Since, free amino acids are used in gluconeogentic pathway to glucose production, reduced levels of protein synthesis in fish exposed to insecticides.

Transaminase play an important role in breakdown of protein to free amino acids which may be used an energy source for glyconegenic pathways or used to synthesis new proteins to repair damaged tissues. So, change in plasma free amino acid levels indicates either an increase or a decrease in protein catabolism or biosynthesis.

Aspartate transaminase (AST), or serum glutamic oxaloacetic transaminase (SGOT) is a pyridoxal phosphate (PLP)-dependent transaminase enzyme. AST catalyzes the reversible transfer of $\alpha$-amino group between aspartate and glutamate and, as such, is an important enzyme in amino acid metabolism. Alanine transaminase or ALT is a transaminaseenzyme. It is also called serum glutamic pyruvic transaminase (SGPT). It catalyzes the transfer of an amino group from alanine to $\alpha$-ketoglutarate, the products of this reversible transamination reaction being pyruvate and glutamate. Aspartate aminotransferase and alanine aminotransferase are found in the liver, heart, skeletal muscle, kidney, pancreas, spleen, erythrocyte, brain and gills (Banaee et al., 2011). Tyrosine aminotransferase (or tyrosine transaminase) is an enzyme present in the liver and catalyzes the conversion of tyrosine to 4-hydroxyphenylpyruvate. Alteration in deamination and transamination of amino acid are associated with changes in nitrogen metabolism, which can be detected in terms of plasma nitrogenous metabolite levels. Free amino acid is also contributed in the formation of excretory product by the process of conjugation.

The increase in intracellular levels of ROS can lead to lipid peroxidation resulting in an increased permeability of liver cell membrane. As a result, liver enzymes including AST and ALT are released into plasma. In this sense, if the cellular injury is chronic AST and ALT levels will remain elevated (Srivastava et al., 2004; Rao, 2006). Increased activities of AST and ALT were observed in plasma of Channa punctatus (Agrahari et al., 2007) exposed to organophosphorus pesticides. Banaee et al., (2008) have reported increased levels of AST and ALT followed by the exposure of common carp to diazinon. Similarly, ROS produced from the metabolism of organophosphate insecticide could be damaged other tissues such as gills, muscle, heart, kidney and spleen causing the leakage of enzymes into plasma (Banaee et al., 2011).

Impact of different insecticides on the hormones involved in the process of protein synthesis can also affect the tissue protein levels. This was in conformity with the effects of dimethoate on C. punctatus (Tripathi et al., 2003). Similar changes in protein content was observed in Labeo rohitha (Ramani, 2001), Etroplus maculatus (Sulekha and Mercy, 2011), Anabas testudineus 
(Sulekha, 2002; Sulekha and Mercy, 2009) exposed to monocrotophos and phosphamidon. Histological damage to various tissues, especially the liver tissue, caused by exposure to insecticides can also decrease the tissue's ability to synthesis protein. For example, Murray et al., (2003) announced that organophosphate insecticides through methylation and phosphorylation of cellular proteins may lead to a reduction in the reconstruction of necrotic tissues.

In case, due to the presence of unsaturated and sulphuric molecules in the biochemical structure of some amino acids such as phenylalanine, mitonin, cysteine, histidine, and tryptophan that they are sensitive and vulnerable to free radicals and specifically reactive oxygen species (Sureda et al., 2006; Tejada et al., 2007) and it helps breaking the sequence of amino acids, aggregation of amino acid chains and even changing the biochemical structure of amino acids and it leads to proteolytic changes in protein compounds (Stadmann, 1992, 1993; Asada and Barba, 2004).

Albumin and globulin make up most of the protein within the body and are measured in the total protein of the plasma. Total protein, albumin and globulin tests are used to monitor the course of diseases in immune disorders, liver dysfunction and impaired kidney activity (Banaee et al., 2011). Banaee et al., (2011) showed that the levels of total protein, albumin and globulin were decreased in fish exposed to diazinon. Decreased total protein levels may be due to starvation, malnutrition and chronic liver diseases (Kirby et al., 1995; Martin et al., 2010). Other authors also found that the levels of total protein and albumin are decreased in the fish exposed to different pollutants and pesticides (Vijayan et al., 1997; Velisek et al., 2009).

\section{Lipid metabolism}

Lipids play an important role as source of energy for fish. Since, most insecticides are lipophilic compounds, they can easy pass through biological barriers which content lipids and accumulate in fat tissue.Lipids molecules are highly susceptible to oxidative reactions. Due to cell membrane lipid peroxidation of unsaturated fatty acids, short chain fatty acids with R$\mathrm{COOH}, \mathrm{R}-\mathrm{OOH}, \mathrm{R}-\mathrm{CHO}$, and $\mathrm{R}-\mathrm{OH}$ bases are created which seriously affect the cellular membrane functions such as the activity of hormone receptors and neural mediators, ion transport channels and the activity of membrane enzymes and the transportation of specific molecules. On the other hand, the formation of malondialdehyde (MAD) during peroxidation process of fatty acids having double bonds can create covalent bonds and polymerize cellular membrane components (Sureda et al., 2006; Tejada et al., 2007). In addition, accumulation of fatty acids in the cytosol increased peroxidation of fatty acids in peroxisomes and the endothelial reticulum, resulting in overproduction of ROS and further damage.

Increased levels of stress hormones such as cortisol in blood of fish exposed to various insecticides, stimulates lipid breakdown in adipose tissue. Both elevated and reduced free fatty acids levels in plasma have been observed in different fish species exposed to insecticides. Changes in cholesterol and triglycerides levels in the blood and other tissues such as muscles and liver of fish treated insecticides indicated that effect of these compounds on lipid metabolism. 


\section{Growth}

From a biochemical point view, ratio of the RNA/DNA can be used as a bio-indicator measure of body growth. Recently, many researchers have focused on the impact of different insecticides on the metabolism of nucleic acid in various tissues of fish (Rathod and Kshirsagar, 2010). Insecticides toxicity indicates change in nucleic acid biosynthesis. Disturbance in the metabolism of nucleic acid can lead to reduction in the RNA content. Also, the deterrent effect of different insecticides such as organophosphate compounds on acid phosphatase and alkaline phosphatase activity in different tissues of fish can also adversely effect on nucleic acid synthesis (Das and Mukherjee, 2000).

Apparently, some insecticides have the potential to inhibit DNA synthesis. For example, the toxicity of dichlorvos has also been related to alterations in DNA replication and chromosome aberration, which causes mutations and cellular hyper-proliferation as a result of local irritation.In fact, insecticides and their metabolites may interfere with the process of DNA synthesis and gene expression by different mechanism. On the other hand, the propagation of malondialdehyde into cells can make the ground for its reaction with nitrogen alkalis of DNA strands (Sureda et al., 2006; Tejada et al., 2007). For example, reduced synthesis of nucleic acids andimpair in the process of proliferation DNA strands as well as inhibition of enzyme activities involved in DNA replication and repair mutations can affect the final product of gene expression. In the other hand, damage to DNA strands caused by oxidative stress and insecticide's metabolites bind to DNA strands (DNA adduct) can lead to impair in the transcription and genes expression. Furthermore, inhibition of DNA synthesis, thus, might affect both protein as well as amino acid levels by decreasing the level of RNA in protein synthesis machinery.

\section{Histopathology}

Histopathological investigations on different tissues of exposed fish are useful tools for toxicological studies and monitoring water pollutions. Tissue alterations in fish exposed to a different concentration of insecticides are a functional response of organisms which provides information on the nature of the toxicant. In histopathology, we can provide information about the health and functionality of organs. Tissues injuries and damages in organs can result in the reduced survival, growth and fitness, the low reproductive success or increase of susceptibility to pathological agents.

Reactive oxygen species (ROS) produced during the insecticides detoxification process in liver tissue may react with vital macromolecules such as lipid, protein, carbohydrate and nucleic acid and result in oxidative damage to aquatic organisms (Üner et al., 2006). ROS derived damage to natural and structure cellular components are generally considered as a serious mechanism involved in the histological disorders (Sepici-Dinçel et al., 2009). On the other hand, organophosphate insecticides through methylation and phosphorylation of cellular proteins (Murray et al., 2003) may lead to a reduction in the reconstruction of necrotic tissues. The deter- 
rent effect of organophosphate insecticides on acid phosphatase and alkaline phosphatase activity in different tissues of fish can also adversely effect on nucleic acid synthesis (Das and Mukherjee, 2000).Frequency and intensity of tissue lesions depend on the concentrations of insecticides and the length of the period fish are exposed to toxins. Nevertheless, many insecticides cause specific or non-specific histopathological damage (Fanta et al., 2003). For example, histopathological lesions in the liver tissue of freshwater fish (Cirrhinus mrigala) (Velmurugan et al., 2009) and common carp carp (Cyprinus carpio) (Banaee et al., 2013) were observed after 10 and 30 days exposure to sublethal concentrations of dichlorvos and diazinon insecticides, respectively. Other researchers reported the same histopathological alterations in different tissues of fish treated with diazinon (Duttaa \& Meijer, 2003; Banaee et al., 2011), deltamethrin (Cengiz, 2006; Cengiz\&Unlu, 2006), fenitrothion (Benli \& Özkul, 2010).The pathological changes in the different tissues such as gill, liver, kidney and spleen of fish treated with different insecticides can disturb homeostasis and lead to physiological disorders in these animals.

\section{Gill}

Fish gills have many important functions including exchange of gases, transport of many mono and divalent ions, excretion of waste nitrogen, and uptake and excretion of various xenobiotics (Zayed and Mohamed, 2004; Evans et al., 2005). Histopathology of gill is the appropriate bioindicator to pollution monitoring. One of the lesions most frequency found on the gills of rainbow trout exposed to $0.1 \mathrm{mg} / \mathrm{L}$ diazinon was epithelial hyperplasia of both primary and secondary epithelium, as can be seen in Figure 1. Our results indicated that the major alterations in the gills of rainbow trout exposed to $0.2 \mathrm{mg} / \mathrm{L}$ diazinon were edma and epithelial hyperplasia, mucosa cell hyperplasia and fusion of the secondary lamellae. Damage to gill tissue may interfere with gas exchange performance of gill and cause respiratory disorders, ion-regulation and osmoregulation dysfunction and inefficacy of the excretion of waste nitrogen metabolite in exposed fish (Nero et al., 2006; Cengiz and Unlu, 2006; Velmurugan et al., 2007). Gill histopathological damage was also observed after exposure of mosquitofish (G. affinis) to deltamethrin (Cengiz and Unlu, 2006), yellow perch and (P. flavescens), goldfish (C. auratus) to oil sands (Nero et al., 2006), yellow perch (P. flavescens) to naphthenic acid (Nero et al., 2006), carp (C. carpio) to deltamethrin (Cengiz, 2006), and rainbow trout (O. mykiss) to maneb and carbaryl (Boran et al., 2010).

\section{Liver}

Histopathological analysis reported important alterations in liver, including necrosis, and cytoskeleton disarray, changes in nuclear shape and heterochromatin distribution as well as intense damages in Disse's space between hepatocytes and sinusoid vessels. Increased vacuolization of the endothelial cells, morphological derangement and necrosis in the Disse's space were also evidenced in liver fish exposed to diazinon. These results are in accordance with Cattaneo et al. (2008), who reported disorder in hepatocyte's cords, rupture of the cell membrane and vacuolated cytoplasm in liver tissue of silver catfish, Rhamdia quelen, after 
exposure to 2,4-dichlorophenoxiacetic acid (2,4-D) herbicide. Hypertrophy of hepatocytes, significant increase of kupffer cells, circulatory disturbances, focal necrosis, fatty degeneration, nuclear pycnosis and narrowing of sinusoids has been reported in G. affinis and C. punctatus, C. carpioexposed to deltamethrin and heavy metal, respectively (Cengiz and Unlu, 2006; Mishra and Mohanty, 2008; Vinodhini and Narayanan, 2009). Similar histopathological changes were observed in the liver tissue of $O$. niloticus and C. carpio exposed to sub-lethal concentrations of carbaryl and cyfluthrin, respectively (Matos et al., 2007; Sepici-Dinçel et al., 2009). This disturbance in the morphological structure of liver could be associated with a disruption in tissue function, which could be also related to the decreased antioxidant capability in diazinon treated fishes.
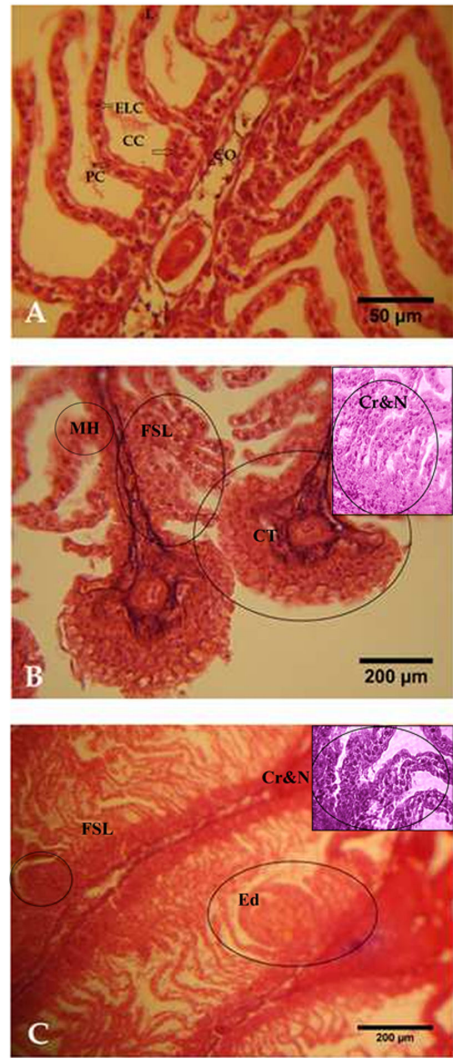

Figure 1. Gills of rainbow trout from the control group (A): Lamella (L), erythrocyte in lamellar capillary (ELC), Chloride cell (CC), Pillar cell (PC), Chondrocytes (CO); Gills of rainbow trout exposed to $0.01 \mathrm{mg} / \mathrm{L}$ diazinon (B): crusting and necrosis of secondary lamellae's epithelium (C\&N), mucosa cell hyperplasia (MH), clubbing tips of gill filaments (CT); Gills of rainbow trout exposed to $0.02 \mathrm{mg} / \mathrm{L}$ diazinon (C): Changes in cartilage tissue of the gill filament, fusion of secondary lamellae (FSL), edema and epithelial hyperplasia (Ed), and the loss of the secondary filaments. Figures are representatives of three replicate experiments (magnification of the sections 400X). 

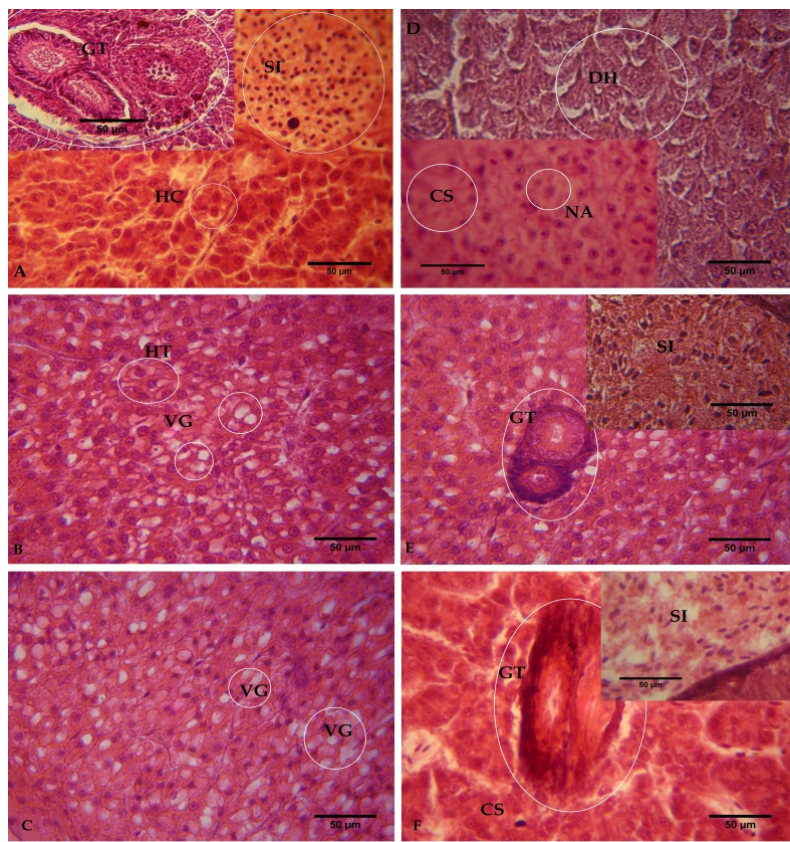

Figure 2. Histopathology of the liver tissue of rainbow trout (Oncorhynchus mykiss) is presented after 28 days of exposure. (A) Liver of control fish showing hexagonal hepatic cells (HC) surrounded with the sinusoidal portal blood (SI); this histopathological slide shows cord of hepatocytes separated by sinusoids containing erythrocytes; bile duct (GT). ( $B$ \& E) Liver of $0.1 \mathrm{mg} / \mathrm{L}$ of diazinon-treated fish showing increased hypertrophy of hepatocytes (HC), vacuolization of cell cytoplasm (VG), hepatocyte cloudy swelling (CS); and at the same time hepatocytes lost their normal polygonal structure. (C \& D \& F) Liver of $0.2 \mathrm{mg} / \mathrm{L}$ of diazinon-treated fish showing increased cellular degradation with cytoplasm vacuolization (VG) and nucleus atrophy (NA). The hepatic cells form clusters; hypertrophy (HT) and the disorientation in the hepatocytes and bile duct obstruction (GT), hepatocyte cloudy swelling (CS), are found to be more prominent. Figures are representatives of three replicate experiments (magnification of the sections 400X).

\section{Kidney}

The head kidney of teleost fish is composed of a variety of cells, including parenchymal cells, lymphoid and hematopoietic tissues (Mela et al., 2007). The functional unit of the kidney is nephron. Morphologically, the nephron of bony fish includes glomerulus, tubules and collecting ducts. In the fish exposed to $0.1 \mathrm{mg} / \mathrm{L}$ diazinon, disorientation in the glomerular structure, dilation in the inter space of urinary tubular, cloudy swelling were observed. Histopathological damage in the kidney tissues of fish exposed to $0.2 \mathrm{mg} / \mathrm{L}$ diazinon were characterized by degeneration in the epithelial cells of renal tubule, necrosis in the hematopoietic tissue, degeneration of glomerulus, dilation of glomerular capillaries, appearance of vacuoles in cytoplasm epithelial cells of renal tubules with hypertrophied cells and narrowing of the tubular lumen. Increase of ROS production in the diazinon metabolism 
process may play an important role in lipid peroxidation of components of cellular membrane resulting in reduced nephron number, glomerular lesions, and reduced glomerular filtration rate. Similar studies showed the toxic effect of insecticides on the histology of kidney of Atlantic salmon (Salmo salar), rainbow trout, O. mykiss, exposed to endosulfan, as pesticide and captan, as the fungicide, respectively (Glover et al., 2007; Boran et al., 2012). These results conform to the deltamethrin and heavy metals effects on kidney tissue of carp that have been reported by Cengiz, (2006) and Vinodhini and Narayanan (2009).

\section{Spleen}

The spleen has a fibrous capsule, and small trabeculae extend into the parenchyma, which can be divided into a red and white pulp. In rainbow trout, the aggregations of melanomacrophages are less well-defined and lack a capsule, but the association with blood vessels and lymphocytes is maintained (Press and Evensen, 1999). Expansion of red pulp with vascular congestion and a significant deposition of hemosiderin granules in a melano-macrophage center are important histopathological damages observed in spleen of fish exposed to both concentrations of diazinon. One of the typical macroscopic changes associated with diazinon toxicity is enlargement and roughness of the spleen. These results are similar to the 3,4dichloroaniline and captanin effects that have been described in common goby (Pomatoschis tusmicrops) and rainbow trout, respectively (Monteiro et al., 2006; Boran et al., 2012).

\section{Digestive tract (intestine)}

The intestine of rainbow trout has a mucosa, submucosa, muscularis and serous membrane. The mucosa epithelium has thin and elongated absorptive cells or enterocytes, goblet cells and lymphocytes. Enterocytes are a single layer of columnar cells with apical brush border and basal elongated nucleus with one nucleolus. There are also often lymphocytes at the basal and apical regions of the epithelium. Atrophy and necrosis of mucosal cell, exfoliate of mucosal epithelium, lymphocyte infiltration to lamina propia, reduction in the elastic properties and capillary bleeding in intestine tissue are important histopathological alterations observed in fish exposed to both concentrations of diazinon. Necrosis, degeneration, and accumulation of lymphocyte in lamina propia were observed in the intestine of mosquitofish, G. affinis, exposed to Thiodan and deltamethrin (Cengiz et al., 2001;Cengiz and Unlu, 2006) and Cirrhinus mrigala treated with lambda-cyhalothrin (Velmurugan et al., 2007). This result is similar to the observations by Glover et al. (2007) in Atlantic salmon (S. salar) to dietary endosulfan exposure.

\section{Gonads}

Some insecticides induced histopathological changes in testes are difficult to study by light microscopy because of the small sizes of the affected cells. Decrease in number and condensation 

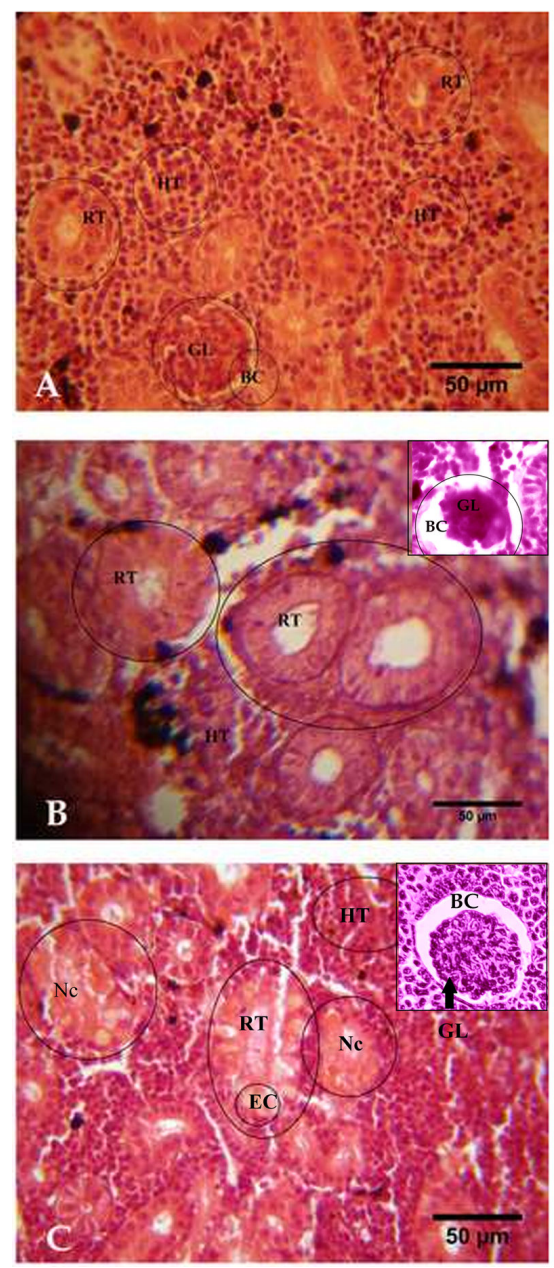

Figure 3. Kidney of rainbow trout from the control group (A): Hematopoietic tissue (HT), renal tube (RT), Glomerulus $(G L)$, Bowman capsule $(B C)$; kidney of rainbow trout exposed to $0.01 \mathrm{mg} / \mathrm{L}$ diazinon (B): dilation in inter space of urinary tubular (DUT), cloudy swelling (CS), glomerular destruction; kidney of rainbow trout exposed to $0.02 \mathrm{mg} / \mathrm{L} \mathrm{diazi-}$ non (C): degeneration of tubular epithelial cells (EC), proliferation of epithelial cells in Bowman capsule, cloudy swelling (CS), severe necrosis in nephritic tissue (Nc). Figures are representatives of three replicate experiments (magnification of the sections $400 \mathrm{X})$.

of spermatogonic cells and appearance of a large number of intertubular vacuoles, cloudy swelling and necrosis of seminiferous tubules are important histopathological alterations observed in testis of fish exposed to diazinon (Duttaa \& Meijer, 2003; Banaee et al., 2009). This is particularly evident with Sertoli cells, which may undergo major insecticides induced changes in morphology. Thus, Spermatocyte necrosis appears to be a common result of diazinon exposure (Banaee et al., 2009). 

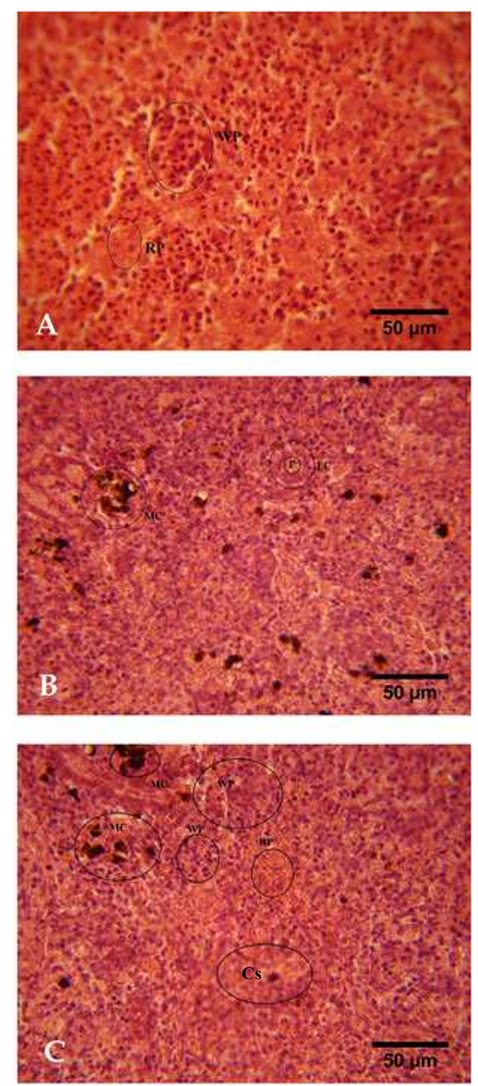

Figure 4. Spleen of rainbow trout from the control group (A): With pulp (WP), Red Pulp (RP), Spleen of rainbow trout exposed to $0.01 \mathrm{mg} / \mathrm{L}$ diazinon (B): Melanomacrophage centers (MC), Ellipsoid cells (EC), Penicillus (P), Expansion of splenic red pulp and melano-macrophage centers, disorientation in ellipsoid cells; Spleen of rainbow trout exposed to $0.02 \mathrm{mg} / \mathrm{L}$ diazinon (C): Disorder in ellipsoid cells, the increase of number and size of melano-macrophage centers, and cloudy swelling in spleen tissue (CS). Figures are representatives of three replicate experiments (magnification of the sections 400X).

The ovaries of $C$. carpio have shown significant changes on exposure to sub-lethal concentration of diazinon. The oocyte with de-shaped yolk vesicles, vacuolated follicular epithelium and degenerative cytoplasm were reported in fish exposed to diazinon by Banaee et al., 2008.

\section{Conclusion}

In conclusion, the present literature review shows that exposure to insecticides, firstly, caused an induction of antioxidant enzyme activities indicating the activation of the insecticides detoxification pathways and the antioxidant defenses. However, acute to chronic insecticides treatment disrupted the behavioral response, alterations hematological, biochemical and im- 

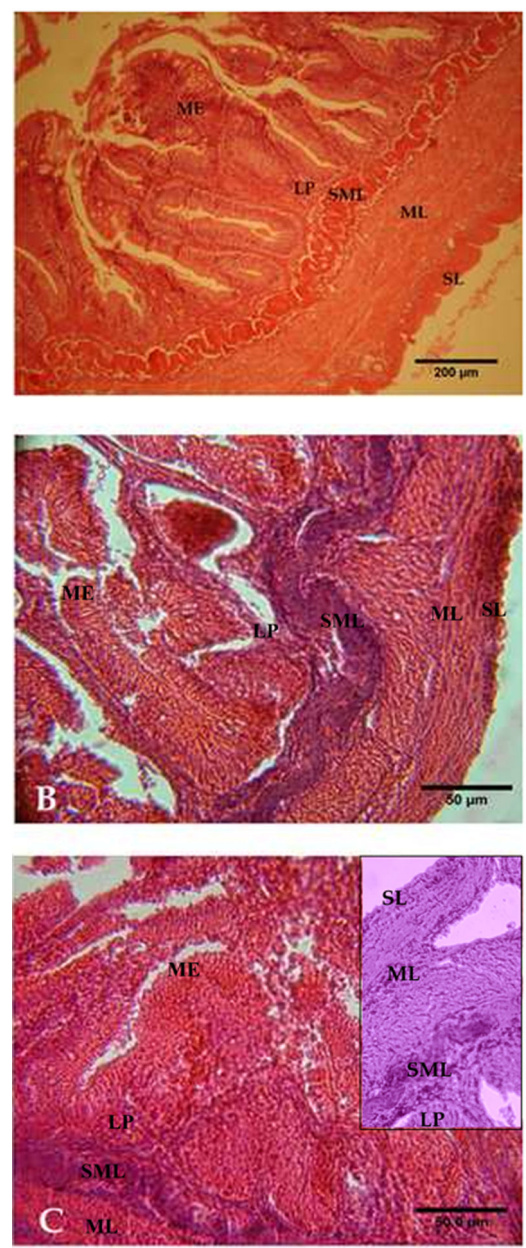

Figure 5. Intestine of rainbow trout from the control group (A): Mucosal epithelium (ME), Lamia's propria (LP), Submucosa layer (SML), Muscularis layer (ML), Serosa layer (SL). Intestine of rainbow trout exposed to $0.01 \mathrm{mg} / \mathrm{L}$ diazinon (B): Desquamating of the mucosal epithelium; Intestine of rainbow trout exposed to $0.02 \mathrm{mg} / \mathrm{L}$ diazinon (C): Mucosal epithelial hyperplasia, severe necrosis in the mucous layer, loss of the intestine microvilli, disorganization in arrangement of circular and longitudinal muscles in muscularis layer, loss of muscle elasticity and flexibility of the intestine. Figures are representatives of three replicate experiments (magnification of the sections 400X).

munological parameters. In addition, the histopathological analysis performed in gills, liver, spleen, kidney, gonads and intestine of fish exposed to different concentration of insecticides reported significant damage in all tissues indicating that it was a useful methodology for monitoring the effects of insecticides on wild and cultured fish. These changes may be potentially disruptive for the survivability of fish in aquaculture farm and natural resources. This fact should be taken into consideration when this insecticide is used for pest control in agriculture fields surrounding surface water and ground water resources. 


\section{Author details}

Mahdi Banaee*

Aquaculture Department, Natural Resource and Environmental Faculty, Behbahan University of Technology, Iran

\section{References}

[1] Agrahari, S, Pandey, K. C, \& Gopal, K. (2007). Biochemical alteration induced by monocrotophos in the blood plasma of fish, Channa punctatus (Bloch). Pesticide Biochemistry and Physiology , 88-268.

[2] Ahmadi, K, Banaee, M, Vosoghei, A. R, Mirvaghefei, A. R, \& Ataeimehr, B. (2012). Evaluation of theimmunomodulatory effects of silymarin extract (Silybum marianum) on some immune parameters of rainbow trout, Oncorhynchusmykiss(Actinopterygii: Salmoniformes: Salmonidae). Acta.Ichthyol.Piscat. , 42(2), 113-120.

[3] Albanis, T, Hela, D, Sakellarides, T, \& Konstantinou, I. (1998). Monitoring of Pesticide Residues and Their Metabolites in Surface and Underground Waters of Imathia (N. Greece) by Means of Solid-Phase Extraction Disks and Gas Chromatography. Journal of Chromatography A, Doi:S0021-9673(98)00304-5., 823, 59-71.

[4] Aldegunde, M, Soengas, J. L, Ruibal, C, \& Andrés, M. D. (1999). Effects of chronic exposure to $\gamma-\mathrm{HCH}$ (lindane) on brain serotonergic and gabaergic systems, and serum cortisol and thyroxine levels of rainbow trout, Oncorhynchus mykiss. Fish Physiology and Biochemistry, , 20, 325-330.

[5] Anees, M. A. (1978). Haematological abnormalities in a freshwater teleost, Channa punctatus (Bloch), exposed to sub-lethal and chronic levels of three organophosphorus insecticides. Int. J. Ecol. Environ. Sci., , 4, 53-60.

[6] Arjmandi, R, Tavakol, M, \& Shayeghi, M. (2010). Determination of organophosphorus insecticide residues in the rice paddies. International Journal Environmental Science Technology, , 7(1), 175-182.

[7] Arufe, M. I, Arellano, J. M, García, L, Albendín, G, \& Sarasquete, C. (2007). Cholinesterase activity in gilthead seabream (Sparus aurata) larvae: Characterization and sensitivity to the organophosphate azinphosmethyl. Aquatic Toxicology, , 84, 328-336.

[8] Auta, J, Balogun, J. K, Lawal, F. A, \& Ipinjolu, J. K. (2002). Short-term effect of dimethoate on behavior of juveniles of Oreochromis niloticus (Trewavas) and Clarias gariepinus (Teugels). Journal of Tropical Biosciences, , 2(1), 55-59.

[9] Aydin, R, \& Köprücü, K. (2005). Acute toxicity of diazinon on the common carp (Cyprinus carpio L.) embryos and larvae. Pesticide Biochemistry and Physiology , 82, 220-225. 
[10] Bagheri, F. Study of pesticide residues (Diazinon, Azinphosmethyl) in the rivers of Golestan province (GorganRoud and Gharehsou), M.Sc. Thesis, Tehran University of Medical Science. Tehran, Iran, ((2007).

[11] Banaee, M, Mirvagefei, A. R, \& Rafei, G. R. Majazi Amiri B ((2008). Effect of sub-lethal diazinon concentrations on blood plasma biochemistry. International Journal Environmental Research, , 2, 189-198.

[12] Banaee, M, Sureda, A, Mirvaghefi, A. R, \& Ahmadi, K. (2011). Effects of diazinon on biochemical parameters of blood in rainbow trout (Oncorhynchus mykiss). Pesticide Biochemistry and Physiology doi:10.1016/j.pestbp.2010.09.001., 99, 1-6.

[13] Banaee, M. (2010). Influence of silymarin in decline of sub-lethal diazinon-induced oxidative stress in rainbow trout (Oncorhynchus mykiss). Ph.D. Thesis, Aquaculture Department, Natural Resource Faculty, University of Tehran, Iran, , 149.

[14] Banaee, M. (2012). Adverse effect of insecticides on various aspects of fish's biology and physiology: Insecticides- Basic and Other Applications Book, Edited by Sonia Soloneski and Marcelo Larramendy, Published by InTech, Chapter , 6, 101-126.

[15] Banaee, M, \& Mirvaghefei, A. R. Majazi Amiri, B. \& Rafei, G.R. ((2012). Biochemical Blood and Histopathological Study of Experimental Diazinon Poisoning in common carp fish (Cyprinus carpio).Journal of Fisheries (Iranian Journal of Natural Resources), 65(2), 119-133.

[16] Banaee, M, \& Mirvaghefei, A. R. Majazi Amiri, B. Rafei, G.R. \& Nematdost, B. ((2011). Hematological and Histopathological Study of Experimental Diazinon Poisoning in common carp fish (Cyprinus carpio). Journal of Fisheries (Iranian Journal of Natural Resources), , 64(1), 1-14.

[17] Banaee, M, Mirvaghefi, A. R, Ahmadi, K, \& Ashori, R. (2009). The effect of diazinon on histophatological changes of testis and ovaries of common carp (Cyprinus carpio). Scientific Journal of Marine Biology, , 1(2), 25-35.

[18] Banaee, M, Mirvaghefi, A. R, Ahmadi, K, \& Banaee, S. (2008). determination of LC $_{50}$ and investigation of acute toxicity effects of diazinon on hematology and serology indices of common carp (Cyprinus carpio). Journal of Marine Science and Technology Research, 3(2), 1-10.

[19] Banaee, M, Sureda, A, Mirvagefei, A. R, \& Ahmadi, K. (2012). Biochemical and histological changes in the liver tissue of Rainbow trout (Oncorhynchusmykiss) exposed to sub-lethal concentrations of diazinon. Fish PhysiolBiochem.Article in press.

[20] Banaee, M, Sureda, A, Mirvagefei, A. R, \& Ahmadi, K. (2012). Histopathological alterations induced by diazinon in rainbow trout, (Oncorhynchus mykiss). Int. J. Environ. Res., Article in press.

[21] Banaee, M, Sureda, A, Mirvagefei, A. R, \& Ahmadi, K. (2012). Biochemical and histological changes in the liver tissue of Rainbow trout (Oncorhynchus mykiss) exposed to sub-lethal concentrations of diazinon. Fish Physiol Biochem. Article in press. 
[22] Banaee, M, Sureda, A, Mirvagefei, A. R, \& Ahmadi, K. (2013). Histopathological alterations induced by diazinon in rainbow trout, (Oncorhynchus mykiss). Int. J. Environ. Res., Article in press.

[23] Banaee, M, \& Ahmadi, K. (2011). Sub-lethal toxicity impacts of endosulfan on some biochemical parameters of the freshwater crayfish (Astacus leptodactylus). Research Journal of Environmental Sciences, , 5(11), 827-835.

[24] Begum, G. (2004). Carbofuran insecticide induced biochemical alterations in liver and muscle tissues of the fish Clarias batrachus (linn) and recovery response. Aquatic Toxicology, , 66, 83-92.

[25] Behrens, A, \& Segner, H. (2001). Hepatic biotransformation enzymes of fish exposed to non-point source pollution in small streams. Journal of Aquatic Ecosystem Stress and Recovery, , 8, 281-297.

[26] Benli, A. Ç. K, \& Özkul, A. (2010). Acute toxicity and histopathological effects of sublethal fenitrothion on Nile tilapia, Oreochromis niloticus. Pesticide Biochemistry and Physiology, , 97, 32-35.

[27] Benli, A. Ç. K, \& Özkul, A. (2010). Acute toxicity and histopathological effects of sublethal fenitrothion on Nile tilapia, Oreochromis niloticus. Pesticide Biochemistry and Physiology, , 97, 32-35.

[28] Betoulle, S, Duchiron, C, \& Deschaux, P. (2000). Lindane differently modulates intracellular calcium levels in two populations of rainbow trout (Oncorhynchus mykiss) immune cells: head kidney phagocytes and peripheral blood leucocytes. Toxicology , $145,203-215$.

[29] Bhatia, S. C, Sharma, S. C, \& Venkitasu, B. T. A. (1972). Acute dieldrin toxicity. Biochemical changes in the blood. Arch. Environ. Health , 24, 369-372.

[30] Boran, H, Altinok, I, \& Capkin, E. (2010). Histopathological changes induced by maneb and carbaryl on some tissues of rainbow trout, Oncorhynchus mykiss Tissue Cell, , 42(3), 158-64.

[31] Boran, H, Capkin, E, Altinok, I, \& Terzi, E. (2012). Assessment of acute toxicity and histopathology of the fungicide captanin rainbow trout.Experimental and Toxicologic Pathology. , 64(3), 175-179.

[32] Botté, E. S, \& Jerry, D. R. Codi King, S. Smith-Keune, C. Negri, A Effects of chlorpyrifos on cholinesterase activity and stress markers in the tropical reef fish Acanthochromis polyacanthus. Marine pollution bulletin. 2012;65(4-9):384-93., 2011.

[33] Bouldin, J. L, Farris, J. L, \& Moore, M. T. Smith Jr, S., and Cooper C.M. ((2007). Assessment of Diazinon Toxicity in Sediment and Water of Constructed Wetlands Using Deployed Corbicula fluminea and Laboratory Testing. Arch. Environ. Contam.Toxicol. , 53, 174-182. 
[34] Box, A, Sureda, A, Galgani, F, Pons, A, \& Deudero, S. (2007). Assessment of environmental pollution at Balearic Islands applying oxidative stress biomarkers in the mussel Mytilus galloprovincialis. Comparative Biochemistry and Physiology, Part C, $146,531-539$.

[35] Box, A, Sureda, A, Galgani, F, Pons, A, \& Deudero, S. (2007). Assessment of environmental pollution at Balearic Islands applying oxidative stress biomarkers in the mussel Mytilus galloprovincialis. Comparative Biochemistry and Physiology, Part C , $146,531-539$.

[36] Casarett and Doull's ToxicologyChapter 6.Biotransformation in Xenobiotics.by A. Parkinson.C. D Klassen, Editor. McGraw-Hill. New York. Fifth Edition (1996).

[37] Cattaneo, R, Loro, V. L, Spanevello, R, Silveira, F. A, Luz, L, Miron, D. S, Fonseca, M. B, Moraes, B. S, \& Clasen, B. (2008). Metabolic and histological parameters of silver catfish (Rhamdia quelen) exposed to commercial formulation of 2,4-dichlorophenoxiacetic acid (2,4-D) herbicide. Pesticide Biochemistry and Physiology , 92, 133-137.

[38] Cengiz, E. I, \& Unlu, E. (2006). Sublethal effects of commercial deltamethrin on the structure ofthe gill, liver and gut tissues of mosquitofish,Gambusia affinis: A microscopic study. Environmental Toxicology and Pharmacology, , 21, 246-253.

[39] Cengiz, E. I. (2006). Gill and kidney histopathology in the freshwater fish Cyprinus carpio after acute exposure to deltamethrin.Environmental Toxicology and Pharmacology, , 22, 200-204.

[40] Cengiz, E. I, \& Unlu, E. (2006). Sub-lethal effects of commercial deltamethrin on the structure of the gill, liver and gut tissues of mosquitofish, Gambusia affinis: A microscopic study. Environmental Toxicology and Pharmacology, , 21, 246-253.

[41] Cengiz, E. I, Unlu, E, \& Balci, K. (2001). The histopathological effects of Thiodan®on the liver and gut of mosquitofish, Gambusia affinis. J. Environ. Sci. Health B. , 36(1), 75-85.

[42] Ceron, J. J, Sancho, E, Ferrando, M. D, Gutierrez, C, \& Andreu, E. (1997). Changes in carbohydrate metabolism in the eel Anguilla anguilla, during shortterm exposure to diazinon. Toxicol. Environ. Chem. , 60, 201-210.

[43] Chambers, J. E, Boone, J. S, Carr, R. L, Chambers, H. W, \& Strauss, D. L. (2002). Biomarkers as predictors in health and ecological risk assessment.Human. Ecol. Risk. Assess., , 8(1), 165-176.

[44] Clark, R. A, \& Klebanoff, S. J. (1975). Neutrophil-mediated tumor cell cytotoxicity: Role of the peroxidase system. The Journal of Experimental Medicine DOI:jem.141.6.1442, 141(6), 1442-1447.

[45] Clifford, M. A, Eder, K. J, Werner, I, \& Hedrick, R. P. (2005). Synergistic effects of esfenvalerate and infectious hematopoietic necrosis virus on juvenile Chinook salmon mortality. Environ. Toxicol. Chem., , 24(7), 1766-1772. 
[46] Cong, N. V, Phuong, N. T, \& Bayley, M. (2008). Brain cholinesterase response in the snakehead fish (Channa striata) after field exposure to diazinon.Ecotoxicology and Environmental Safety , 71, 314-318.

[47] Cong, N. V, Phuong, N. T, \& Bayley, M. (2009). Effects of repeated exposure of diazinon on cholinesterase activity and growth in snakehead fish (Channa striata). Ecotoxicology and Environmental Safety , 72, 699-703.

[48] Cossarini-dunier, M, \& Hattenberger, A. M. (1988). Effect of pesticides (atrazine and lindane) on the replication of spring viremia of carp virus in vitro. Ann. Rech. Vet., , 19, 209-211.

[49] Cuesta, A, Meseguer, J, \& Esteban, M. Á. (2008). Effects of the organochlorines p, p'DDE and lindane on gilthead seabream leucocyte immune parameters and gene expression. Fish Shellish Immunol., 25, 682-8.

[50] Das, B. K, \& Mukherjee, S. C. (2000). Chronic toxic effects of quinalphos on some biochemical parameters in Labeo rohita (Ham.). Toxicology Letters, , 114, 11-18.

[51] Ding, Y, Weston, D. P, You, J, Rothert, A. K, \& Lydy, M. J. (2011). Toxicity of SedimentAssociated Pesticides to Chironomus dilutes and Hyalella Azteca. Arch Environ Contam Toxicol , 61, 83-92.

[52] Dubus, I, Hollis, J, \& Brown, C. (2000). Pesticides in rainfall in Europe. Environmental Pollution, , 110, 331-344.

[53] Dutta, H. M, \& Meijer, H. J. M. (2003). Sublethal effects of diazinon on the structure of the testis of bluegill, Lepomis macrochirus: a microscopic analysis. Environmental Pollution, , 125, 355-360.

[54] Echols, K. P, Brumbaugh, W. G, Orazio, C. E, May, T. W, Poulton, B. C, \& Peterman, P. H. (2008). Distribution of Pesticides, PAHs, PCBs, and Bioavailable Metals in Depositional Sediments of the Lower Missouri River, USA. Arch Environ Contam Toxicol, , 55, 161-172.

[55] Ecobichon, D. J. (2001). Carbamate Insecticides. In: Kriegler, R., Doull, J., Ecobichon, D., Gammon, D., Hodgson, E., Reiter, L., and Ross J., (eds). Handbook of Pesticide Toxicology.2 ${ }^{\text {nd }}$ Edition Academic Press, San Diego, California. , 2-Agents, 1087-1106.

[56] Eder, K. J, Leutenegger, C. M, Köhler, H. R, \& Werner, I. (2009). Effects of neurotoxic insecticides on heat-shock proteins and cytokine transcription in Chinook salmon (Oncorhynchus tshawytscha).Ecotoxicology and Environmental Safety , 72, 182-190.

[57] Evans, D. H, Piermarini, P. M, \& Choe, K. P. (2005). The multifunctional fish gill: dominant site of gas exchange, osmoregulation, acid-base regulation, and excretion of nitrogenous waste. Physiol. Rev. , 85, 97-177.

[58] Ferrari, A, \& Venturino, A. de D'Angelo, A.M.Effects of carbaryl and azinphos methyl on juvenile rainbow trout (Onchorhynchus mykiss) detoxifying enzymes. Insecticide Biochemistry and Physiology, 88: 134-142., 2007a. 
[59] Franco, J. L, Posser, T, Mattos, J. J, Sánchez-chardi, A, Trevisan, R, \& Oliveira, C. S. Carvalho PSM, Leal RB Marques MRF, Bainy ACD, Dafre AL ((2008). Biochemical alterations in juvenile carp (Cyprinus carpio) exposed to zinc: Glutathione reductase as a target. Marine Environmental Research , 66, 88-89.

[60] Fujii, Y, \& Asaka, S. (1982). Metabolism of diazinon and diazoxon in fish liver preparations. Bulletin of Environmental Contamination and Toxicology , 29-455.

[61] Garcia, S, Ake, C, Clement, B, Huebuer, H, Donnelly, K, \& Shalat, S. (2001). Initial Results of Environmental Monitoring in the Texas Rio Grande Valley. Environmental International, , 26, 465-474.

[62] Ghassempour, A, Mohammadkhah, A, Najafie, M, \& Rajabzadeh, M. (2002). Monitoring of the pesticide diazinon in soil, stem and surface water of rice fields. Analytical Sciences: The International Journal of The Japan Society For Analytical Chemistry. , 18(7), 779-783.

[63] Ghosh, K, \& Banerjee, V. (1993). Alteration in blood parameters in the fish Heteropneustes fossilis exposed to dimethoate., Environ, Ecol., , 11, 979-981.

[64] Ghosh, T. K. (1987). Impact of commercial grade hexagor and sumidon on behavior and some aspects of carbohydrate metabolism in fish Cyprinus carpio Uttar Pradesh, J. Zool., , 7, 48-62.

[65] Gilbert, S. C, Emmett, M, Menter, A, Silverman, A, \& Klintmalm, G. (1989). Cyclosporine therapy for psoriasis: Serum creatinine measurements are an unreliable predictor of decreased renal function. Journal of the American Academy of Dermatology , 21-470.

[66] Girón-pérez, M. I, Velázquez-fernández, J, Díaz-resendiz, K, Díaz-salas, F, Cantomontero, C, Medina-diíaz, I, Robledo-marenco, M, Rojas-garcía, A, \& Zaitseva, G. (2009). Immunologic parameters evaluations in Nile tilapia (Oreochromis niloticus)exposed to sublethal concentrations of diazinon. Fish \& Shellfish Immunology , 27-383.

[67] Glover, C. N, Petri, D, Tollefsen, K. E, Jørum, N, Handy, R. D, \& Berntssen, M. H. G. (2007). Assessing the sensitivity of Atlantic salmon (Salmo salar) to dietary endosulfan exposure using tissue biochemistry and histology. Aquatic Toxicology, , 84, 346-355.

[68] Gokcimen, A, Gulle, K, Demirin, H, Bayram, D, Kocak, A, \& Altuntas, I. (2007). Effects of diazinon at different doses on rat liver and pancreas tissues. Pesticide Biochemistry and Physiology , 87-103.

[69] Gormley, K. L, \& Teather, K. L. (2003). Developmental, behavioral, and reproductive effects experienced by Japanese medaka (Oryzias latipes) in response to short-term exposure to endosulfan. Ecotoxicology and Environmental Safety, , 54, 330-338.

[70] Hai, D. Q, Varga, S. I, \& Matkovics, B. (1997). Organophosphate effects of antioxidant system of carp (Cyprinus carpio) and catfish (Ictalurus nebulosus). Comp. Biochem. Physiol. , 117, 83-88. 
[71] Halappa, R, \& David, M. (2009). Behavioural responses of the fresh water fish, Cyprinus carpio (Limmaeus) following sublethal exposure to chlorpyrifos. Turkish Journal of Fisheries and Aquatic Sciences , 9, 233-238.

[72] Hamm, J. T, Wilson, B. W, \& Hinton, D. E. (2001). Increasing uptake and bioactivation with development positively modulate diazinon toxicity in early life stage medaka (Oryzias latipes). Toxicological Sciences, , 61, 304-313.

[73] Hernández, A. F, Gómez, M. A, Pérez, V, García-lario, J. V, Pena, G, Gil, F, López, O, Rodrigo, L, Pino, G, \& Pla, A. (2006). Influence of exposure to pesticides on serum components and enzyme activities of cytotoxicity among intensive agriculture farmers. Environment Research, 102-70.

[74] Holland, M. M, Steven, M, \& Gallin, J. I. (1997). Disorders of Granulocytes and Monocytes.In Harrison's Principles of Internal Medicine, edited by Anthony S. Fauci, et al.New York, McGraw-Hill.

[75] Hope, B. K. (2012). Using Legacy Data to Relate Biological Condition to Cumulative Aquatic Toxicity in the Willamette River Basin (Oregon, USA). Arch Environ Contam Toxicol. 62(3):424-37.

[76] Husain, K, \& Ansari, R. A. (1988). Influence of cholinergic and adrenergicblocking drugs on hyperglycemia and brain glycogenolysis in diazinon-treated animals, Can. J. Physiol. Pharmacol. , 66-1144.

[77] Isik, I, \& Celik, I. (2008). Acute effects of methyl parathion and diazinon as inducers for oxidative stress on certain biomarkers in various tissues of rainbow trout (Oncorhynchus mykiss). Pesticide Biochemistry and Physiology , 92, 38-42.

[78] Jin, Y, Chen, R. J, Liu, W. P, \& Fu, Z. W. (2010). Effect of endocrine disrupting chemicals on the transcription of genes related to the innate immune system in the early developmental stage of zebrafish (Danio Rerio). Fish Shellfish Immunol. , 28, 854-61.

[79] Jos, A, Pichardo, S, Prieto, A. I, Repetto, G, Vazquez, C. M, Moreno, I, \& Camean, A. M. (2005). Toxic cyanobacterial cells containing microcystins induce oxidative stress in exposed tilapia fish (Oreochromis sp.) under laboratory conditions. Aquatic Toxicology, , 72, 261-271.

[80] Katagi, T. (2010). Bioconcentration, Bioaccumulation, and Metabolism of Pesticides in Aquatic Organisms.D.M. Whitacre (ed.), Reviews of Environmental Contamination and Toxicology, Reviews of Environmental Contamination and Toxicology. , 204

[81] Keizer, J, Agostino, D, Nagel, G, Gramenzi, R, \& Vittozzi, F. L ((1993). Comparative diazinon toxicity in guppy and zebra fish: different role of oxidative metabolism. Environmental Toxicology and Chemistry, , 12, 1243-1250.

[82] KeizerJ. D’Agostino, G.Nagel, R. Volpe, T. Gnemid, P. Vittozzi, L. ((1995). Enzymological differences of $\mathrm{AChE}$ and diazinon hepatic metabolism: correlation of in vitro data 
with the selective toxicity of diazinon to fish species. The Science of the Total Environment , 171, 213.

[83] Khoshbavar-rostami, H. A, Soltani, M, \& Hassan, H. M. D. (2006). Immune response of great sturgeon (Huso huso) subjected to long-term exposure to sublethal concentration of the organophosphate, diazinon. Aquaculture, , 256, 88-94.

[84] Kirby, G. M, Stalker, M. J, Gordon, S, Quinn, B. A, Van Schooten, F. J, \& Hayes, M. A. (1995). Influences of chronic cholangiohepatitis and cholestasis on hepatic metabolism of benzo[a]pyrene in white suckers (Catostomus commersoni) from industrially polluted areas of Lake Ontario. Carcinogenesis. , 16, 2923-2929.

[85] Kitamura, S, Kadota, T, Yoshida, M, Jinno, N, \& Ohta, S. (2000). Whole-body metabolism of the organophosphorus pesticide, fenthion, in goldfish, Carassius auratus. Comp. Biochem.Physiol.C , 126, 259-266.

[86] Koprucu, S. S, Koprucu, K, \& Urail, M. S. (2006). Acute toxicology of synthetic pyrethroid deltamethrin to fingerling European catfish (Silirus glanis L.). Bulletin of Environmental Contamination and Toxicology, , 76, 59-65.

[87] Küster, E. (2005). Cholin and carboxylesterase activities in developing zebrafish embryos (Danio rerio) and their potential use for insecticide hazard assessment. Aquatic Toxicology , 75, 76-85.

[88] Lam, P. K. S, \& Wu, R. S. S. (2003). Use of biomarkers in environmental monitoring.Presented at the STAP Workshop on the use of bioindicators, biomarkers and analytical methods for the analysis of POPs in developing countries. December 2003., 10-12.

[89] Lazzari, R, Duarte, M. F, Morsch, V. M, Pippi, A. L, \& Vieira, V. P. (2006). Effects of Clomazone Herbicide on hematological and some parameters of protein and carbohydrate metabolism of silver catfish Rhamdia quelen.Ecotox. Environ. Safe.,, 65, 48-55.

[90] Li, Z. H, Li, P, \& Randak, T. (2010a). Ecotoxocological effects of short-term exposure to a human pharmaceutical Verapamil in juvenile rainbow trout (Oncorhynchus mykiss) Comparative Biochemistry and Physiology, Part C, , 152, 385-391.

[91] Li, Z. H, Zlabek, V, Grabic, R, Li, P, \& Randak, T. (2010a). Modulation of glutathionerelated antioxidant defense system of fish chronically treated by the fungicide propiconazole. Comparative Biochemistry and Physiology, Part C, doi:10.1016/j.cbpc. 2010.06.006., 152, 392-398.

[92] Li, Z. H, Zlabek, V, Velíšek, J, Grabic, R, Machová, J, Kolarová, J, Li, P, \& Randák, T. (2011b). Antioxidant responses and plasma biochemical characteristics in the freshwater rainbow trout, Oncorhynchus mykiss, after acute exposure to the fungicide propiconazole Czech J. Anim. Sci., , 56(2), 61-69.

[93] Li, Z. H, Zlabek, V, Velíšek, J, Grabic, R, Machová, J, Kolarová, J, Li, P, \& Randák, T. (2010c). Hepatic antioxidant status and hematological parameters in rainbow trout, 
Oncorhynchus mykiss, after chronic exposure to carbamazepine Chemico-Biological Interactions , 183, 98-104.

[94] Luo, Y, Su, Y, Lin, R, Shi, H, \& Wang, X. (2006). Chlorophenol induced ROS generation in fish Carassius auratus based on the EPR method. Chemosphere , 65-1064.

[95] Lydy, M. J, \& Austin, K. R. (2004). Toxicity Assessment of Pesticide Mixtures Typical of the Sacramento-San Joaquin Delta Using Chironomus tentans. Arch. Environ. Contam.Toxicol. , 48, 49-55.

[96] Martin, S. A, Douglas, A, Houlihan, D. F, \& Secombes, C. J. (2010). Starvation alters the liver transcriptome of the innate immune response in Atlantic salmon (Salmo salar). BMC Genomics. , 11, 41-48.

[97] Mast, M. A, Foreman, W. T, \& Skaates, S. V. (2007). Current-Use Pesticides and Organochlorine Compounds in Precipitation and Lake Sediment from Two HighElevation National Parks in the Western United States. Arch. Environ. Contam.Toxicol. , 52, 294-305.

[98] Matos, P, Fontainhas-fernandes, A, Peixoto, F, Carrola, J, \& Rocha, E. (2007). Biochemical and histological hepatic changes of Nile tilapia Oreochromis niloticus exposed to carbaryl. Pesticide Biochemistry and Physiology , 89, 73-80.

[99] Mckim, J. M, \& Lein, G. L. (2001). Toxic responses of the skin. In: Target Organ Toxicity in Marine and Freshwater Teleosts, edited by D. Schlenk and W.H. Benson, London, UK, Taylor \& Francis, , 151-223.

[100] Mela, M, Randi, M. A. F, Ventura, D. F, Carvalho, C. E. V, \& Pelletier, E. and Oliveira Ribeiro, C.A. ((2007). Effects of dietary methylmercury on liver and kidney histology in the neotropical fish Hoplias malabaricus. Ecotoxicology and Environmental Safety, , $68,426-435$.

[101] Mena TorresF. Pfennig, S. Arias Andrés Mde, J. Márquez-Couturier, G. Sevilla, A. Protti, C.M. ((2012). Acute toxicity and cholinesterase inhibition of the nematicide ethoprophos in larvae of gar Atractosteus tropicus (Semionotiformes: Lepisosteidae). Rev Biol Trop. , 60(1), 361-8.

[102] Mishra, A. K, \& Mohanty, B. (2008). Acute toxicity impacts of hexavalent chromium on behavior and histopathology of gill, kidney and liver of the freshwater fish, Channa punctatus (Bloch). Environmental Toxicology and Pharmacology , 26, 136-141.

[103] Monteiro, M, Quintaneiro, C, Pastorinho, M, Pereira, M. L, Morgado, F, Guilhermino, L, \& Soares, A. M. V. M. (2006). Acute effects of 3,4-dichloroaniline on biomarkers and spleen histology of the common goby Pomatoschistus microps. Chemosphere , 62, 1333-1339.

[104] Murray, R. K, Granner, D. K, Mayes, P. A, \& Rodwell, V. W. (2003). Harper's Illustrated Biochemistry, 26 edition, Lange Medical Books/McGraw-Hill, Medical Publishing Division, 702 page. 
[105] Mushigeri, S. B, \& David, M. (2005). Fenvalerate induced changes in the Ach and associated AchE activity in different tissues of fish Cirrhinus mrigala (Hamilton) under lethal and sub-lethal exposure period. Environmental Toxicology and Pharmacology, $20,65-72$.

[106] Nabb, D. L, \& Mingoia, R. T. Yang, Ch. Han, X. (2006). Comparison of basal level metabolic enzyme activities of freshly isolated hepatocytes from rainbow trout (Oncorhynchus mykiss) and rat.Aquat.Toxicol. , 80, 52-59.

[107] Nath, R, \& Banerjee, V. (1996). Effect of pesticidesmethylparathion and cypermethrin on the air-breathingfish Heteropneustes fossilis, Environ.Ecol. 14, 163165.

[108] Nebbia, C. (2001). Biotransformation Enzymes as Determinants of Xenobiotic Toxicity in Domestic Animals. The Veterinary Journal , 2001(161), 238-252.

[109] Nemcsok, J, Asztalos, B, Vig, E, \& Orban, L. (1987). The effect of anorganophosphorus pesticide on the enzymes of carp (Cyprinus carpio L.), Acta Biol. Hung. , 38, 77-85.

[110] Nero, V, Farwell, A, Lee, L. E. J, \& Van Meer, T. MacKinnon, M.D., and Dixon, D.G. (2006). The effects of salinity on naphthenic acid toxicity to yellow perch: Gill and liver histopathology. Ecotoxicology and Environmental Safety, , 65, 252-264.

[111] Nero, V, Farwell, A, Lister, A, Van Der Kraak, G, Lee, L. E. J, \& Van Meer, T. MacKinnon, M.D., and Dixon, D.G. (2006). Gill and liver histopathological changes in yellow perch (Perca flavescens) and goldfish (Carassius auratus) exposed to oil sands process-affected water. Ecotoxicology and Environmental Safety, , 63, 365-377.

[112] Oruc, E. (2012). Oxidative stress responses and recovery patterns in the liver of Oreochromis niloticus exposed to chlorpyrifos-ethyl. Bull Environ Contam Toxicol. , 88(5), 678-84.

[113] Oruç, E. Ö, \& Usta, D. (2007). Evaluation of oxidative stress responses and neurotoxicity potential of diazinon in different tissues of Cyprinus carpio. Environmental Toxicology and Pharmacology, , 23, 48-55.

[114] Ozmen, I, Bayir, A, Cengiz, M, Sirkecioglu, A. N, \& Atamanalp, M. (2004). Effects of water reuse system on antioxidant enzymes of rainbow trout (Oncorhynchus mykiss W., 1792). Vet.Med.Czech, , 49(10), 373-378.

[115] Patil, V. K, \& David, M. (2008). Behaviour and respiratory dysfunction as an index of malathion toxicity in the freshwater fish, Labeo rohita (Hamilton). Turkish Journal of Fisheries and Aquatic Sciences , 8, 233-237.

[116] Piner, P, \& Uner, N. (2012). Oxidative and apoptotic effects of lambda-cyhalothrin modulated by piperonyl butoxide in the liver of Oreochromis niloticus. Environ Toxicol Pharmacol. , 33(3), 414-20.

[117] Press, C. M, \& Evensen, Ø. (1999). The morphology of the immune system in teleost fishes. Fish \& Shellfish Immunology , 9, 309-318. 
[118] Rahiminezhhad, M, Shahtaheri, S. J, \& Ganjalim, R. Rahimi Foroushani A, Golbabaei F (2009). Moleculary imprinted soild phase extraction for trace analysis of diazinon in drinking water. Iranian Journal of Environmental Health Science and Engineering. , 6, 97-106.

[119] Rao, J. V. Toxic effects of novel organophosphorus insecticide (RPR-V) on certain biochemical parameters of euryhaline fish, Oreochromis mossambicus. Pesticide Biochemistry and Physiology , 86-78.

[120] Rathod, N. D, \& Kshirsagar, R. V. (2010). Quantification of nucleic acid from fresh water fish Punctius arenatus (Day), exposed to pesticides.International Journal of Advanced Biotechnology and Research. 1(1) 2010, , 43-51.

[121] Rezg, R, Mornagui, B, Arbi, M, Kamoun, A, Fazaa, S, \& Gharbi, N. (2006). Effect of subchronic exposure to malathion on glycogenphosphorylase and hexokinase activities in rat liver using native PAGE, Toxicology , 223, 9-14.

[122] Richards, S. M, \& Kendall, R. J. (2002). Biochemical effects of chlorpyrifos on two developmental stages of Xenopus laevis. Environ. Toxicol. Chem.,, 21, 1826-1835.

[123] Rooijakkers, S. H. M, \& Van Strijp, J. A. G. (2007). Bacterial complement evasion. Molecular Immunology 44 (1-3): 23-32

[124] Saha, S, \& Kaviraj, A. (2009). Effects of cypermethrin on some biochemical parameters and its amelioration through dietary supplementation of ascorbic acid in freshwater catfish Heteropneustes fossilis. Chemosphere , 74, 1254-1259.

[125] Salvo, L. M, Bainy, A. C. D, Ventura, E. C, Marques, M. R. F, Silva, J. R. M, \& Klemz, C. C. Silva de Assis, H.C. (2012). Assessment of the sublethal toxicity of organochlorine pesticide endosulfan in juvenile common carp (Cyprinus carpio). Journal of Environmental Science and Health, Part A: Toxic/Hazardous Substances and Environmental Engineering, doi:, 47(11), 1652-1658.

[126] Schlenk, D. (2005). Pesticide biotransformation in fish: In Mommsen TP, Moon TW (ed) Biochemistry and Molecular Biology of Fishes, Elsevier B.V., , 6, 171-190.

[127] Scholz, N. L, Truelove, N. K, French, B. L, Berejikian, B. A, Quinn, T. P, Casillas, E, \& Collier, T. K. (2000). Diazinon disrupts antipredator and homing behaviors in chinook salmon (Oncorhynchus tshawytscha). Can. J. Fish.Aquat. Sci. , 57, 1911-1918.

[128] Scott, G. R, \& Sloman, K. A. (2004). The effects of environmental pollutants on complex fish behaviour: integrating behavioural and physiological indicators of toxicity. Aquatic Toxicology, , 68, 369-392.

[129] Sepici-dinçel, A, Benli, AÇK, Selvi, M, Sarikaya, R, Sahin, D, Özkul, I. A, \& Erkoç, F. (2009). Sublethal cyfluthrin toxicity to carp (Cyprinus carpio L.) fingerlings: Biochemical, hematological, histopathological alterations. Ecotoxicology and Environmental Safety, , 72, 1433-1439. 
[130] Sharma, R. M. (1990). Effect of Endosulfan on acid and alkaline phosphatase activity in liver, kidney, and muscles of Channa gachua. Bulletin of Environmental Contamination and Toxicology , 44, 443-448.

[131] Shea, T. b, \& Berry, E. S. (1984). Suppression of interferon synthesis by the pesticide carbaryl as a mechanism for enhancement of goldfish virus-2 replication. Appl. Environ. Microbiol. , 47, 250-252.

[132] Shea, T. B. (1983). Enhancement of goldfish virus-2 in vitro replication by the pesticides carbaryl and toxaphane. Appl. Environ. Microbiol., 45, 1859-1864.

[133] Shelley, L. K, Balfry, S. K, Ross, P. S, \& Kennedya, C. J. (2009). Immunotoxicological effects of a sub-chronic exposure to selected current-use pesticides in rainbow trout (Oncorhynchus mykiss). Aquatic Toxicology „, 92, 95-103.

[134] Siwicki, A. K, Cossarini-dunier, M, Studnicka, M, \& Demael, A. (1990). In vivo effect of the organophosphorus insecticide trichlorphon on imunne response of carp (Cyprinus carpio). II. Effect of high doses of trichlorphon on nonspecific immune response, Ecotoxicol. Environ. Saf., 19, 99-105.

[135] Srivastava, A. S, Oohara, I, Suzuki, T, Shenouda, S, Singh, S. N, Chauhan, D. P, \& Carrier, E. (2004). Purification and properties of cytosolic alanine aminotransferase from the liver of two freshwater fish, Clarias batrachus and Labeorohita. Comparative Biochemistry and Physiology Part B: Biochemistry and Molecular Biology , 137, 197-207.

[136] Stegeman, J. J, \& Hahn, M. E. (1994). Biochemistry and molecular biology of monooxygenases: current perspectives on forms, functions and regulation of cytochrome P450 in aquatic species, in: Malins, D.C. Ostrander, G.K. (Eds.), Aquatic Toxicology: Molecular, Biochemical Cellular Perspectives, CRC Press, Boca Raton, Florida, , 87-206.

[137] Straus, D. L, Schlenk, D, \& Chambers, J. E. (2000). Hepatic microsomal desulfuration and dearylation of chlorpyrifos and parathion in fingerling channel catfish: lack of effect from Aroclor 1254. Aquat.Toxicol. , 50, 141-149.

[138] Sulekha, B. T, \& Mercy, T. V. A. (2011). Pesticide induced changes in the proximate composition of a freshwater fish for estimating maximum allowable toxicant concentrations of the pesticide under tropical conditions. Indian. J. Fish., , 58(2), 85-90.

[139] Sun, F, \& Chen, H. S. (2008). Monitoring of pesticide chlorpyrifos residue in farmed fish: Investigation of possible sources. Chemosphere , 71, 1866-1869.

[140] Sureda, A, Box, A, Deudero, S, \& Pons, A. (2009). Reciprocal effects of caulerpenyne and intense herbivorism on the antioxidant response of Bittium reticulatum and Caulerpa taxifolia. Ecotoxicology and Environmental Safety, , 72, 795-801.

[141] Sureda, A, Box, A, Ensenat, M, Alou, E, Tauler, P, Deudero, S, \& Pons, A. (2006). Enzymatic antioxidant response of a labrid fish (Coris julis) liver to environmental caulerpenyne. Comparative Biochemistry and Physiology, Part C, , 144, 191-196. 
[142] Svodova, M, Luskova, V, Drastichova, J, \& Zlabek, V. (2001). The effect of Diazinon on hematological indices of common carp (Cyprinus carpio. L). Acta Vet.Brno; , 70, 457-465.

[143] Tarahi Tabrizi S (2001). Study of pesticide residues (diazinonmalathion, metasytoux) in the Tabriz Nahand River, M.Sc. Thesis, Tehran University of Medical Science, Tehran, Iran, p., 1-88.

[144] Tejada, S, Sureda, A, Roca, C, Gamundí, A, \& Esteban, S. (2007). Antioxidant response and oxidative damage in brain cortex after high dose of pilocarpine. Brain Research Bulletin, doi:10.1016/j.brainresbull.2006.10.005., 71, 372-375.

[145] Toal, D. G, Afonso, L. O. B, \& Iwama, G. K. (2004). Stress response of juvenile rainbow trout (Oncorhynchus mykiss) to chemical cues released from stressed conspecifics. Fish Physiology and Biochemistry , 30, 103-108.

[146] Todd, N. E, \& Leeuwen, M. V. (2002). Effects of Sevin (Carbaryl Insecticide) on Early Life Stages of Zebrafish (Danio rerio). Ecotoxicology and Environmental Safety , 53, 267-272.

[147] Toffaletti, J. G, \& Mcdonnell, E. H. (2008). Variation of serum creatinine, cystatin C and creatinine clearance tests in persons with normal renal function. Clinica Chimica Acta, 395, 115-119.

[148] Tripathi, P. K, Srivastava, V. K, \& Singh, A. (2003). Toxic effects of dimethoate (organophosphate) on metabolism and enzyme system of freshwater teleost fish Channa punctatus. Asian Fisheries Science, , 16, 349-359.

[149] Epa, U. S. (2005). Aquatic life ambient water quality criteria Diazinon Final.Office of Science and Thechnology Whashington, DC. (CAS Registry (333-41)

[150] Epa, U. S. A. (2003). Diazinon Fact Sheet: Notice of Availability of Draft Criteria Document and Request for Scientific Views, United States Environmental Protection Agency, EPA-F-03-004., 822.

[151] Üner, N, Oruç, E. Ö, Sevgiler, Y, Sahin, N, Durmaz, H, \& Usta, D. (2006). Effects of diazinon on acetylcholinesterase activity and lipid peroxidation in the brain of Oreochromis niloticus. Environmental Toxicology and Pharmacology, , 21, 241-245.

[152] Velasco-santamaría, Y. M, Handy, R. D, \& Sloman, K. A. (2011). Endosulfan affects health variables in adult zebrafish (Danio rerio) and induces alterations in larvae development. Comparative Biochemistry and Physiology, Part C , 153, 372-380.

[153] Velisek, J, Svobodova, Z, \& Piackova, V. (2009). Effects of acute exposure to bifenthrin on some haematological, biochemical and histopathological parameters of rainbow trout (Oncorhynchus mykiss). Veterinarni Medicina, 54, (3): 131-137.

[154] Velisek, J, Svobodova, Z, \& Machova, J. (2008). Effects of bifenthrin on some haematological, biochemical and histopathological parameters of common carp (Cyprinus carpio L.). Fish Physiology and Biochemistry , 35, 583-590. 
[155] Velmurugan, B, Selvanayagam, M, Cengiz, E. I, \& Unlu, E. (2009). Histopathological Changes in the Gill and Liver Tissues of Freshwater Fish, Cirrhinus mrigala Exposed to Dichlorvos. An International Journal Brazilian Archives of Biology and Technology , 52(5), 1291-1296.

[156] Velmurugan, B, Selvanayagam, M, Cengiz, E. I, \& Unlu, E. (2007). Histopathology of lambda-cyhalothrin on tissues (gill, kidney, liver and intestine) of Cirrhinus mrigala. Environmental Toxicology and Pharmacology , 24, 286-291.

[157] Viant, M. R, Pincetich, C. A, \& Tjeerdema, R. S. (2006). Metabolic effects of dinoseb, diazinon and esfenvalerate in eyed eggs andalevins of Chinook salmon (Oncorhynchus tshawytscha)determined by H NMR metabolomics. Aquatic Toxicology, , 77, 359-371.

[158] Vijayan, M. M, Feist, G, Otto, D. M. E, Schreck, C. B, \& Moon, T. W. (1997). Tetracholorobiphenyl affects cortisol dynamics and hepatic function in rainbow trout. Aquatic Toxicology , 37-87.

[159] Vinodhini, R, \& Narayanan, M. (2009). Heavy Metal Induced Histopathological Alterations in Selected Organs of the Cyprinus carpio L. (Common Carp). Int. J. Environ. Res., 3(1), 95-100.

[160] Vryzas, Z, Vassiliou, G, Alexoudis, C, \& Papadopoulou-mourkidou, E. (2009). Spatial and temporal distribution of pesticide residues in surface waters in northeastern Greece. Water Research, , 43, 1-10.

[161] Wang, C, Lu, G, Gui, J, \& Wang, P. (2009). Sublethal effects of pesticide mixtures on selected biomarkers of Carassius auratus. Environmental Toxicology and Pharmacology , 28, 414-419.

[162] Wang, X, Xing, H, Li, X, Xu, S, \& Wang, X. (2011). Effects of atrazine and chlorpyrifos on the mRNA levels of IL- $1 \beta$ and IFN- $\gamma 2 b$ in immune organs of common carp. Fish \& Shellfish Immunology , 31, 126-133.

[163] Wauchope, R. D. (1978). The pesticide content of surface water draining from agricultural fields. Journal of environmental quality , 7, 459-472.

[164] Weiss, L. R, Bryant, L, \& Filzhygh, O. G. (1984). Blood sugar levels following acute poisoning with parathion and 1-naphthyl $\mathrm{N}$-methyl carbamate (sevin) in three species. Toxicol. Appl. Pharmacol., 6, 363-369.

[165] Werimo, K, Bergwerff, A. A, \& Seinen, W. (2009). Residue levels of organochlorines and organophosphates in water, fish and sediments from Lake Victoria-Kenyan portion. Aquatic Ecosystem Health \& Management, , 12, 337-341.

[166] Werner, I, \& Oram, J. (2008). Pyrethroid insecticides conceptual model. Sacramento (CA): Delta Regional Ecosystem Restoration Implementation Plan. , 1-43.

[167] Xu, C, Tu, W, Lou, C, Hong, Y, \& Zhao, M. (2010). Enantioselective separation and zebrafish embryo toxicity of insecticide beta-cypermethrin. Journal of Environmental Sciences , 22(5), 738-743. 
[168] Zayed, A. E, \& Mohamed, S. A. (2004). Morphological study on the gills of two species of fresh water fishes: Oreochromis niloticusand Clarias gariepinus. Ann. Anat. , 186, 295-304.

[169] Zelikoff, J. T, Raymond, A, Carlson, E, Li, Y, Beaman, J. R, \& Anderson, M. (2000).

Biomarkers of immunotoxicity in fish: from the lab to the ocean. Toxicol.Lett. (Amst.), 325-331. 
